\title{
Rapid Upregulation of $\alpha 7$ Nicotinic Acetylcholine Receptors by Tyrosine Dephosphorylation
}

\author{
Chang-Hoon Cho, ${ }^{1}$ Weifeng Song, ${ }^{1}$ Katherine Leitzell, ${ }^{2}$ Esther Teo, ${ }^{3}$ Annal D. Meleth, ${ }^{1}$ Michael W. Quick, ${ }^{2,3}$ and \\ Robin A. J. Lester ${ }^{1}$ \\ ${ }^{1}$ Department of Neurobiology, University of Alabama at Birmingham, Birmingham, Alabama 35294, and 2Neuroscience Graduate Program and \\ ${ }^{3}$ Department of Biological Sciences, University of Southern California, Los Angeles, California 90089
}

$\alpha 7$ nicotinic acetylcholine receptors (nAChRs) modulate network activity in the CNS. Thus, functional regulation of $\alpha 7$ nAChRs could influence the flow of information through various brain nuclei. It is hypothesized here that these receptors are amenable to modulation by tyrosine phosphorylation. In both Xenopus oocytes and rat hippocampal interneurons, brief exposure to a broad-spectrum protein tyrosine kinase inhibitor, genistein, specifically and reversibly potentiated $\alpha 7 \mathrm{nAChR}$-mediated responses, whereas a protein tyrosine phosphatase inhibitor, pervanadate, caused depression. Potentiation was associated with an increased expression of surface $\alpha 7$ subunits and was not accompanied by detectable changes in receptor open probability, implying that the increased function results from an increased number of $\alpha 7 \mathrm{nAChRs}$. Soluble $\mathrm{N}$-ethylmaleimide-sensitive factor attachment protein receptor-mediated exocytosis was shown to be a plausible mechanism for the rapid delivery of additional $\alpha 7 \mathrm{nAChRs}$ to the plasma membrane. Direct phosphorylation/ dephosphorylation of $\alpha 7$ subunits was unlikely because mutation of all three cytoplasmic tyrosine residues did not prevent the genisteinmediated facilitation. Overall, these data are consistent with the hypothesis that the number of functional cell surface $\alpha 7 \mathrm{nAChRs}$ is controlled indirectly via processes involving tyrosine phosphorylation.

Key words: addiction; hippocampus; protein kinase; protein phosphatase; receptor turnover; exocytosis

\section{Introduction}

Remodeling of neuronal circuitry may be a mechanism through which addictive drugs, such as nicotine, exert their long-term behavioral effects (Mansvelder and McGehee, 2002). The nature of such modifications are, at present, unknown; however, changes in the number and/or function of nicotinic acetylcholine receptors (nAChRs) that occurs during and after chronic nicotine treatment (Marks et al., 1983; Schwartz and Kellar, 1983) could lead to an alteration in synaptic transmission. $\alpha 7$ subunitcontaining nAChRs on hippocampal GABAergic neurons are functionally upregulated after $1-4 \mathrm{~d}$ of exposure to nicotine (Kawai and Berg, 2001). Because activation of these receptors regulates the level of inhibition in the hippocampus (Alkondon et al., 1997a; Jones and Yakel, 1997; Frazier et al., 1998a,b), druginduced changes in receptor function could alter the flow of information through this network. $\alpha 7 \mathrm{nAChRs}$ are regulated by a variety of cellular mechanisms including phosphorylation. A direct role for cellular serine/threonine phosphorylation was demonstrated from the finding that calmodulin (CaM) kinase II inhibition could attenuate a use-dependent rundown of these receptors (Liu and Berg, 1999). However, the precise mechanism

Received Dec. 5, 2003; revised March 2, 2005; accepted March 2, 2005.

This work was supported by United States Public Health Service Grant DA11940.

Correspondence should be addressed to Dr. Robin A. J. Lester, Department of Neurobiology, CIRC560, University

of Alabama at Birmingham, 1719 Sixth Avenue South, Birmingham, AL 35294-0021. E-mail: rlester@nrc.uab.edu.

C.-H. Cho's present address: Department of Internal Medicine, Yale University, New Haven, CT 06520-8020.

DOI:10.1523/JNEUROSCI.5389-03.2005

Copyright $\odot 2005$ Society for Neuroscience $\quad$ 0270-6474/05/253712-12\$15.00/0 linking phosphorylation and receptor function remains unknown, especially because the $\alpha 7$ subunit does not seem to be a substrate for direct CaM kinase II phosphorylation (Moss et al., 1996).

At the neuromuscular junction (NMJ), another form of protein phosphorylation of tyrosine residues is involved in a variety of functional roles (Mei and Si, 1995). Inhibition of tyrosine phosphorylation prevents the agrin-mediated tyrosine phosphorylation of the muscle nAChR $\beta$ subunit and receptor clustering (Wallace et al., 1991). In addition, tyrosine phosphorylation of these receptors leads to an increase in the rate of receptor desensitization, implying that the functional properties of ligandgated ion channels can be regulated by this type of covalent modification (Hopfield et al., 1988). Less is known about the effects of tyrosine phosphorylation on neuronal-type nAChRs. Inhibition of protein tyrosine kinases (PTKs) in chick ciliary ganglion neurons causes a slow downregulation in the number of $\alpha 3$ subunitcontaining receptors but has little effect on $\alpha 7 \mathrm{nAChRs} \mathrm{(De} \mathrm{Kon-}$ inck and Cooper, 1995; Haselbeck and Berg, 1996). Conversely, long-term treatment of hippocampal neurons with neuregulin, which activates receptor PTKs, produces a robust increase in the number of $\alpha$-bungarotoxin ( $\alpha \mathrm{BTX}$ )-binding sites and a concomitant increase in $\alpha 7$ receptor-mediated currents (Liu et al., 2001). In addition, the neurotrophin family of receptor tyrosine kinase ligands seems to be important for maintenance of $\alpha 7$ receptor clusters on hippocampal GABAergic interneurons (Kawai et al., 2002 ) and can induce $\alpha 7$ mRNA transcription in PC12 cells (Hendersen et al., 1994). Collectively, these data imply that $\alpha 7$ 
receptors may be under the influence of tyrosine phosphorylation, which can lead to changes in receptor number and function. Recently, it has become clear that tyrosine phosphorylation can very rapidly modulate receptor function (Davis et al., 2001). Therefore, in the present study, we have examined the acute effects of tyrosine kinases and protein tyrosine phosphatases (PTPs) on $\alpha 7$ receptor function in Xenopus oocytes and hippocampal neurons.

\section{Materials and Methods}

\section{Chemicals}

All salts and drugs were obtained from Sigma (St. Louis, MO), unless stated otherwise. Activated pervanadate solution was prepared freshly for each experiment and made by mixing a stock solution of vanadate with $\mathrm{H}_{2} \mathrm{O}_{2}$ in an equal molar ratio. Genistein and daidzein were dissolved in $0.1 \%$ DMSO. The src kinase inhibitor PP2 and botulinum toxin (BoNT) A were obtained from Calbiochem (La Jolla, CA). Chlorisondamine was a gift from Novartis Pharmaceuticals (Summit, NJ).

\section{Xenopus oocyte preparation and cDNA injection}

The Xenopus oocyte culture was described in detail previously (Quick and Lester, 1994). Briefly, portions of oocyte-containing ovaries were removed surgically from anesthetized toads, defolliculated using collagenase A (Boehringer Mannheim, Indianapolis, IN), and maintained at $18^{\circ} \mathrm{C}$ in medium containing ND96 (in mM: $96 \mathrm{NaCl}, 2 \mathrm{KCl}, 1 \mathrm{MgCl}_{2}$, and 5 HEPES, pH 7.4), $1.8 \mathrm{mM} \mathrm{CaCl}_{2}, 50 \mu \mathrm{g} / \mathrm{ml}$ gentamicin, and $5 \%$ horse serum. Subunit cRNAs were synthesized in vitro (Message Machine; Ambion, Austin TX) from linearized plasmid templates of rat cDNA clones containing the appropriate polymerase promoter. RNA was aliquoted in DEPC-treated water and stored at $-70^{\circ} \mathrm{C}$ until use. Oocytes were injected with 150-300 ng of $\alpha 7$ subunit RNA. For heteromeric nAChRs, $\alpha$ and $\beta$ subunits were injected in 1:1 ratios (25 ng each). In the case of NMDA receptors, NR1a and NR2b subunits were injected in a 1:2.5 ratio (135-360 ng). The NMDA receptor subunit constructs were generously provided by Dr. S. F. Treynelis (Emory University, Atlanta, GA) and Dr. S. Heinemann (Salk Institute, La Jolla, CA). cRNA for the cystic fibrosis transmembrane conductance regulator (CFTR) and dynamin (wild type or mutant) was injected at 4 and $15 \mathrm{ng}$ per oocyte, respectively. These latter constructs were kindly provided by Dr. K. Kirk (University of Alabama at Birmingham).

\section{Electrophysiology in oocytes}

Whole-cell currents were measured at room temperature, 2-10 d after RNA injection, using a GeneClamp 500 amplifier (Axon Instruments, Foster City, CA) in a standard two-microelectrode voltage-clamp configuration. Electrodes were filled with $3 \mathrm{~mm} \mathrm{KCl}$ and had a resistance of 0.5-2.0 M $\Omega$. Oocytes were clamped between -40 and $-65 \mathrm{mV}$ and superfused continuously in ND96 containing $1.8 \mathrm{mM} \mathrm{CaCl}_{2}$. All drugs were applied in this solution. ACh and (-)-nicotine tartrate (nicotine) were prepared from frozen stock solutions $(100 \mathrm{mM})$. Atropine $(1 \mu \mathrm{M})$ was included in the superfusion solution to block any endogenous muscarinic responses. Solutions were gravity fed via a six-way manual valve (Rainin Instruments, Woburn, MA) to the oocyte in the recording chamber. Solution exchange considerations were discussed by Fenster et al. (1997). There was no attempt to correct for non-instantaneous agonist application (Papke and Thinschmidt, 1998). All currents were recorded on a Pentium-based computer with AxoScope software (Axon Instruments) after $50-100 \mathrm{~Hz}$ low-pass filtering at a digitization frequency of $200 \mathrm{~Hz}$. Peak currents at $\mathrm{EC}_{50}$ concentrations were typically in the range of $100 \mathrm{nA}$ to $2 \mu \mathrm{A}$, although currents as small as $5 \mathrm{nA}$ could be resolved accurately and larger currents were common during dose-response experiments (see Fig. 5).

\section{Site-directed mutagenesis}

For site-directed mutagenesis, the PCR method was used. Nicotinic receptor $\alpha 7$ genes were inserted in pCDNA3, and T7 and SP6 promoter primers were used with specific primers to generate point mutations. The sequences of mutagenic primers for various $\alpha 7$ tyrosine residues were as follows: $\alpha 7-\mathrm{Y} 317 \mathrm{~F}$, forward, $5^{\prime}$-GTGCTGAGATTTCACCACCATG-3'; reverse, $5^{\prime}$-CATGGTGGTGAAATCTCAGCAC-3'; $\alpha 7$-Y386F, forward, 5'-CAACCTGCTCTTCATTGGCTTC-3'; reverse, 5' -GAAGCCAATGAAGAGCAGGTTG-3'; $\alpha 7$-Y446F, forward 5'-GGAGGTCCGCTTCATCGCCAAC-3'; reverse, 5' -GTTGGCGATGAAGCGGACCTCC-3'.

PCR conditions were adjusted (e.g., annealing temperature and extension time) to get specific PCR products. Fifty microliters of PCR consisted of 50 pm primer, $1 \mu \mathrm{g}$ of template DNA, $5 \mu \mathrm{l}$ of $10 \times$ reaction buffer, deoxynucleotide triphosphate mixture (200 $\mu \mathrm{M}$ each), nucleasefree using double-distilled $\mathrm{H}_{2} \mathrm{O}\left(\mathrm{ddH}_{2} \mathrm{O}\right)$, and $2 \mu \mathrm{l}$ of $P f u$ polymerase (Promega, Madison, WI). PCR products were run on $1-1.2 \%$ Trisacetate EDTA agarose gels and extracted using a Qiaquick gel purification kit (Qiagen, Valencia, CA). Purified PCR products were used for another round of PCR or subcloned into pCDNA3 vector using appropriate restriction enzyme sites. Ligation reactions were performed at $12^{\circ} \mathrm{C}$ with T4 DNA ligase (Promega). Mutations were confirmed by DNA sequencing at the University of Alabama at Birmingham sequencing facility.

\section{Rat hippocampal slice preparation and recording}

After decapitation under halothane-induced anesthesia, brains were removed from 10- to 25-d-old rats and placed into ice-cold artificial CSF (ACSF) (in mM: $125 \mathrm{NaCl}, 2.5 \mathrm{KCl} ; 1.25 \mathrm{NaH}_{2} \mathrm{PO}_{4}, 25 \mathrm{NaHCO}_{3}, 11$ D-glucose, $1 \mathrm{MgCl}_{2}$, and $2 \mathrm{CaCl}_{2 \text {; }}$ bubbled with $95 \% \mathrm{O}_{2} / 5 \% \mathrm{CO}_{2}$ ). Coronal brain slices (200-300 $\mu \mathrm{m}$ thick) containing the hippocampus were prepared using a vibratome and maintained in a holding chamber at room temperature. For recording, brain slices were transferred to a chamber mounted on the fixed stage of an upright microscope and superfused continuously with ACSF. Neurons (three to four cell layers deep) were readily visualized on a video monitor through a differential interference contrast optics/infrared-sensitive camera. Whole-cell patch-clamp recordings were obtained using 2-5 $\mathrm{M} \Omega$ patch pipettes filled with an intracellular solution (in mM: 130 Cs-methanesuphonate, $10 \mathrm{CsCl}, 10$ EGTA, 10 HEPES, $2 \mathrm{~N}-(2,6-$ dimethylphenylcarbamoylmethyl)triethylammonium bromide (QX-314), and $2 \mathrm{Mg}$-ATP). Series resistance was compensated $\approx 80 \%$ on-line. Currents were low-pass filtered at $1 \mathrm{~Hz}$ and digitized at $4 \mathrm{~Hz}$ using an Axopatch-1D amplifier and pClamp software on a Pentium-based computer. Drugs were applied either via the bath or directly to single cells using localized pressure ejection. All experiments were performed in the presence of $200 \mathrm{~nm}$ TTX.

\section{Surface biotinylation and immunoblotting}

Biotinylation experiments were performed essentially as described previously (Qian et al., 1997; Davis et al., 1998). Oocytes were rinsed in ND96 and incubated with $2 \mathrm{ml}$ of a solution containing $1 \mathrm{mg} / \mathrm{ml}$ sulfoNHS biotin (Pierce, Rockford, IL) in ND96/Ca/Mg for $20 \mathrm{~min}$ at $4^{\circ} \mathrm{C}$ with gentle shaking. The biotinylation solution was removed by two washes in ND96/Ca/Mg plus $100 \mathrm{~mm}$ glycine and quenched in this solution by incubating the oocytes at $4^{\circ} \mathrm{C}$ for $45 \mathrm{~min}$ with gentle shaking. The oocytes were homogenized with $1 \mathrm{ml}$ radioimmunoprecipitation assay (RIPA) buffer (100 mm Tris-Cl, pH 7.4, 150 mm NaCl, 1 mм EDTA, 1\% Triton X-100, $1 \%$ sodium deoxycholate, $0.1 \%$ SDS, $1 \mu \mathrm{g} / \mathrm{ml}$ leupeptin, 1 $\mu \mathrm{g} / \mathrm{ml}$ aprotinin, and $250 \mu \mathrm{M}$ PMSF). The homogenates were centrifuged at $20,000 \times g$ at $4^{\circ} \mathrm{C}$ for $60 \mathrm{~min}$. The supernatant fractions $(300 \mu \mathrm{l})$ were incubated with an equal volume of Immunopure Immobilized Monomeric Avidin beads (Pierce) for $60 \mathrm{~min}$. The beads were washed three times with RIPA buffer, and adsorbed proteins were eluted with SDS sample buffer (62.5 mm Tris-Cl, pH 6.8, 2\% SDS, and $100 \mathrm{~mm}$ $\beta$-mercaptoethanol) at room temperature for $30 \mathrm{~min}$. Analysis was performed on aliquots of the supernatant fraction after adsorption and centrifugation (nonbiotinylated, intracellular fraction) and of the bead eluate (biotinylated, surface fraction). Western blotting was performed using anti-nicotinic receptor polyclonal antibodies at a 1:200 dilution (Santa Cruz Biotechnology, Santa Cruz, CA). Monoclonal anti-actin antibodies (1:1000 dilution; Sigma) were used to verify that the impermeant biotinylating reagent was not labeling intracellular proteins.

\section{$\alpha B T X$ binding}

${ }^{125}$ I-labeled $\alpha B T X$-binding assays in oocytes. Surface saturation binding assays were performed on intact oocytes as described previously (Fenster et al., 1999). Briefly, oocytes were removed from incubation media and rinsed in ND96 plus $\mathrm{Ca}^{2+}$ for several minutes. Individual oocytes were 
next placed into single wells of a 96-well plate containing $40 \mu \mathrm{l}$ of ND96 plus $\mathrm{Ca}^{2+}$. Stocks $(5 \times)$ of ${ }^{125}$ I-labeled $\alpha$ BTX $\left(\left[{ }^{125} \mathrm{I}\right] \alpha \mathrm{BTX}\right)$ (Amersham Biosciences, Arlington Heights, IL) were prepared by dilution in ND96 plus $\mathrm{Ca}^{2+}$. The assay (60 min at room temperature) was initiated with the addition of $10 \mu \mathrm{l}$ of $5 \times\left[{ }^{125} \mathrm{I}\right] \alpha \mathrm{BTX}$ to the well, followed by gentle mixing for several seconds. The assay was terminated by drawing the oocyte into the cut end of a pipette tip along with $4 \mu \mathrm{l}$ of assay solution. The oocyte was then pipetted sequentially into four different $2.5 \mathrm{ml}$ wells containing ice-cold ND96 plus $\mathrm{Ca}^{2+}$, solubilized in $1 \%$ SDS, and counted for radioactivity. Nonspecific binding was determined by the addition of $1 \mu \mathrm{M}$ unlabeled $\alpha \mathrm{BTX}$ to the assay; nonspecific binding was subtracted from total binding to determine receptor-specific binding.

$\left[{ }^{125} I\right] \alpha B T X-b i n d i n g$ assays in neurons. Primary hippocampal neuron cultures were prepared from embryonic day 18 rat embryos. Briefly, the embryos were decapitated rapidly in accordance with protocols approved by the Animal Care and Use Committee at the University of Southern California. Hippocampi were dissected out and placed in icecold HBSS using ddH $\mathrm{H}_{2} \mathrm{O}$ (in g/L: $0.14 \mathrm{CaCl}_{2}, 0.4 \mathrm{KCl}, 0.06 \mathrm{KH}_{2} \mathrm{PO}_{4}, 0.1$ $\mathrm{MgCl}_{2}, 0.1 \mathrm{MgSO}_{4}, 8 \mathrm{NaCl}, 0.35 \mathrm{NaHCO}_{3}$, and $\left.0.09 \mathrm{Na}_{2} \mathrm{HPO}_{4}, \mathrm{pH} 7.4\right)$. Hippocampi were cut into $2 \mathrm{~mm}$ pieces after careful removal of meninges. The small pieces were transferred to $5 \mathrm{ml}$ of warmed HBSS with 100 $\mathrm{U}$ of papain and incubated at $37^{\circ} \mathrm{C}$ for $45 \mathrm{~min}$. Tissue was triturated using warm culture medium (Neurobasal medium, B27 supplement, and 0.5 mM L-glutamine). Neurons were plated onto poly-L-lysine-coated 24well dishes at a density of $\sim 1 \times 10^{5}$ cells per well. Approximately $1 \mathrm{~h}$ after plating, neurons were observed to attach to the bottom of the plate, and the medium was changed to warm fresh medium. Neurons were fed every 3-4 $\mathrm{d}$ by replacing one-half the medium with fresh medium.

Binding to surface $\alpha 7$ receptors was performed as described previously (Ridley et al., 2001). The cultures were washed three times for $5 \mathrm{~min}$ with warm culture medium. Total binding was determined by adding $\left.{ }^{125} \mathrm{I}\right] \alpha \mathrm{BTX}$ (10 nM final concentration) to the cultures for $2 \mathrm{~h}$ at $25^{\circ} \mathrm{C}$. Nonspecific binding was determined from cultures additionally treated with $1 \mu \mathrm{M}$ unlabeled $\alpha$ BTX. Similar nonspecific binding results were obtained from assays using $300 \mu \mathrm{M}$ methyllycaconitine or $5 \mathrm{~mm}$ choline (data not shown). To terminate the assay, the cultures were washed three times for $1 \mathrm{~min}$ in PBS and solubilized in $0.005 \%$ SDS. Aliquots from the same well were counted for radioactivity and used to determine protein concentration. All measurements were made in triplicate.

Binding to $\alpha 7$ receptors in whole-cell lysates was performed as described previously (Peng et al., 1997). Culture medium was replaced by ice-cold homogenization buffer (in mM: $150 \mathrm{NaCl}, 5 \mathrm{KCl}, 1.8 \mathrm{CaCl}_{2}, 1.3$ $\mathrm{MgCl}_{2}$, and 33 Tris, $\mathrm{pH} 7.4$ ). Neurons were dislodged mechanically from the plate, homogenized, and centrifuged at $45,000 \times g$ for $10 \mathrm{~min}$ at $4^{\circ} \mathrm{C}$, and the crude membrane pellet was resuspended in PBS. Total binding was determined by incubating the suspension with $\left[{ }^{125} \mathrm{I}\right] \alpha \mathrm{BTX}(10 \mathrm{nM}$ final concentration) overnight at $4^{\circ} \mathrm{C}$. Unbound label was removed by repelleting the suspension, followed by washing three times in PBS. Nonspecific binding was determined from suspensions additionally treated with $1 \mu \mathrm{M}$ unlabeled $\alpha \mathrm{BTX}$. All measurements were made in triplicate.

\section{Data analysis}

Concentration-response curves were fit with logistic expressions to estimate $\mathrm{EC}_{50}$ values. All data are expressed as the mean \pm SEM. For statistical comparisons of mean data, weighted-means $t$ tests were performed. Significance was determined at $p<0.05$.

\section{Results}

Tyrosine kinase and phosphatase inhibitors differentially modulate $\alpha 7$ nAChR function in oocytes

To test whether tyrosine phosphorylation modulates the function of nAChRs, the effects of both PTK and PTP inhibitors were studied on $\alpha 7$ receptor-mediated currents in Xenopus oocytes. After stable responses to $100 \mu \mathrm{M}$ ACh were obtained, the broadspectrum tyrosine kinase inhibitor genistein $(10 \mu \mathrm{M})$ was introduced into the recording chamber, and $\alpha 7$ currents were monitored after a $5 \mathrm{~min}$ incubation. Figure 1 shows that, at this concentration of genistein, $\alpha 7$ currents were potentiated twofold.
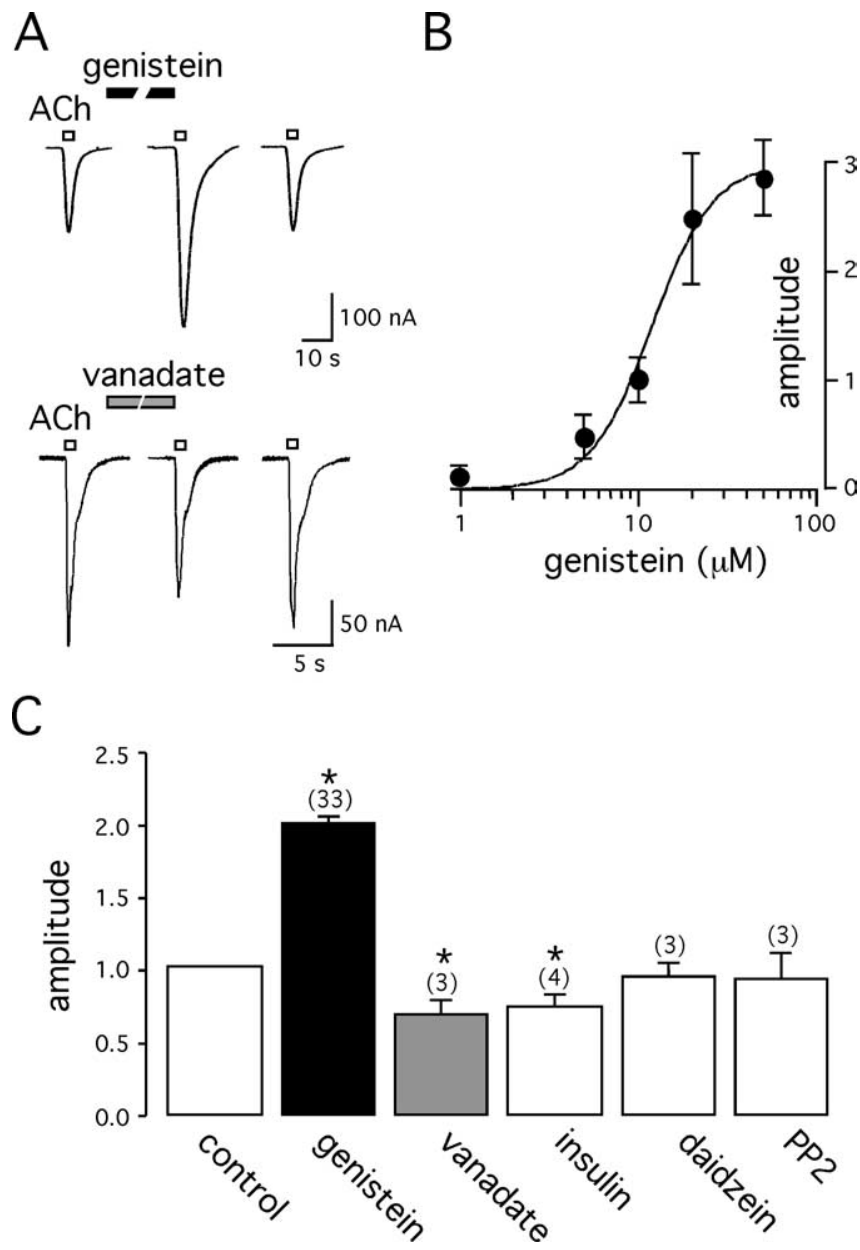

Figure 1. $\alpha 7 \mathrm{nAChR}$ function is modulated by inhibitors of tyrosine kinases and tyrosine phosphatases. $\boldsymbol{A}$, Representative examples of ACh-induced $\alpha 7$ currents before, during, and after 5 min applications of $10 \mu \mathrm{m}$ genistein (top traces) and $10 \mu \mathrm{m}$ pervanadate (bottom traces). $\boldsymbol{B}$, Plot showing the concentration dependence of potentiation of currents by genistein. C, Summary histogram illustrating the mean effects of inhibition or activation of PTKs and PTPS on $\alpha 7$ currents. The concentrations of drugs were as follows: genistein, $10 \mu \mathrm{m}$; pervanadate, 10 $\mu \mathrm{m}$; insulin, $5 \mu \mathrm{m}$; daidzein, $10 \mu \mathrm{M}$; PP2, $10 \mu \mathrm{M}$.

The half-maximally effective concentration $\left(\mathrm{EC}_{50}\right)$ of genistein was $12 \mu \mathrm{M}$ (Fig. $1 \mathrm{~B}$ ), a value consistent with its ability to inhibit tyrosine phosphorylation (Akiyama et al., 1987). The inactive analog of genistein, daidzein $(10 \mu \mathrm{M})$, was without effect (Fig. $1 C)$. It may be expected that inhibition of tyrosine phosphorylation would only be effective in inducing functional changes if it occurred in the presence of ongoing tyrosine dephosphorylation. In line with this idea, a 5 min incubation with the protein tyrosine phosphatase inhibitor pervanadate $(10 \mu \mathrm{M})$ reduced the amplitude of $\alpha 7$ receptor-mediated currents (Fig. 1). However, because pervanadate may not be entirely selective for tyrosine phosphatases (Herzig and Neumann, 2000), its actions may be explained by enhanced phosphorylation at serine/threonine residues. In further support of a role for tyrosine phosphorylation, insulin (10 $\mu \mathrm{M}$ ), which activates its own receptor tyrosine kinase, mimicked the effect of pervanadate, producing a significant reduction of $\alpha 7$ responses (Fig. 1C). To test whether nonreceptor tyrosine kinases are implicated in this form of nAChR modulation, a high concentration of PP2 $(10 \mu \mathrm{M})$, which inhibits the src family of PTKs (Hanke et al., 1996), was applied to oocytes for 5 min. Unlike genistein, this inhibitor failed to potentiate $\alpha 7$ currents (Fig. 1C). The effect of genistein was essentially reversible after a $5 \mathrm{~min}$ 
A

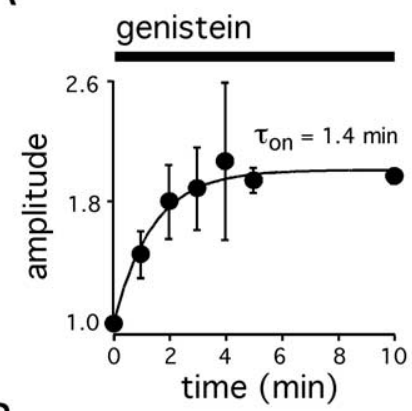

B

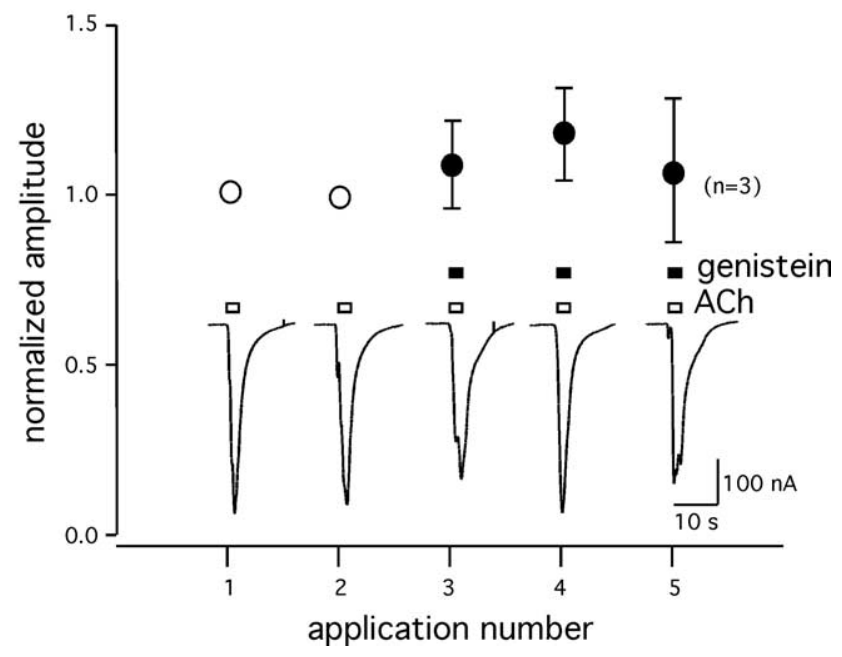

Figure 2. Potentiation is rapid, reversible, and does not result from a direct interaction of genistein with $\alpha 7 \mathrm{nAChRs}$. $\boldsymbol{A}$, Plots showing the time courses of the onset of and recovery from the effects of genistein. Solid lines represent single exponents fitted to the data. $\tau_{\text {on }}$ and $\tau_{\text {off }}$ are the exponential time constants for onset and recovery, respectively. $\boldsymbol{B}$, Plot illustrating (open symbols) the lack of effect of coapplication of $10 \mu \mathrm{m}$ genistein (filled bars) and ACh (open bars) on the peak amplitude of $\alpha 7$ receptor-mediated currents. Applications were at $5 \mathrm{~min}$ intervals. Inset, Example traces of $\mathrm{ACh}$-induced responses in the absence and presence of genistein.

washout period ( $95 \pm 10 \%$ control) (Fig. $2 A$ ), although recovery from pervanadate was less complete (recovery at $15 \mathrm{~min}, 75 \pm$ $9 \%)$. Overall, these data suggest that tyrosine dephosphorylation enhances $\alpha 7$ receptor responses, whereas tyrosine phosphorylation leads to a reduction in function.

A series of control experiments was then performed to demonstrate that the genistein-induced enhancement of ACh currents most likely resulted from kinase inhibition and was specific to $\alpha 7$ receptors. $\alpha 7$ receptor-mediated responses can be potentiated by a number of allosteric compounds including $\mathrm{Ca}^{2+}$ (Eisele et al., 1993), cholinesterase inhibitors (Pereira et al., 1993), and ivermectin (Krause et al., 1998). To eliminate the possibility that genistein was acting through one of these (or other) positive allosteric sites, $\mathrm{ACh}$ and genistein were coapplied for brief $(\approx 5 \mathrm{~s})$ periods. The data show that, under this protocol, genistein was unable to potentiate ACh currents (Fig. 2 B), implying that the potentiation likely resulted from a slower inhibition of intracellular PTKs.

The ACh-induced current through $\alpha 7$ receptors could conceivably contain a component that is mediated by $\mathrm{Ca}^{2+}$ influx and subsequent stimulation of an endogenous $\mathrm{Cl}^{-}$conductance in oocytes (Barish, 1983; Seguela et al., 1993). Thus, the effects of manipulation of tyrosine kinases/phosphatases could be manifest as an altered $\mathrm{Cl}^{-}$current rather than the directly evoked $\alpha 7$ cur- rent. Two approaches were taken to eliminate any $\mathrm{Cl}^{-}$component of the response. First, the $\mathrm{Cl}^{-}$current was pharmacologically blocked using flufenamic acid (FFA) (White and Aylwin, 1990). At near maximal concentrations $(100 \mu \mathrm{M})$, FFA partially blocked the $\alpha 7$ receptor-mediated response: the ACh-induced current was reduced by $32 \pm 6 \%(n=3)$. Although the block could have resulted from inhibition of the $\mathrm{Cl}^{-}$conductance, a direct action on the nAChR is also possible (Zwart et al., 1995). More importantly, in the presence of this blocker, genistein was still able to potentiate the $\alpha 7$ responses (data not shown). A second set of experiments was designed to circumvent any nonspecific actions of the pharmacological agents. Nondesensitizing $\mathrm{GABA}_{\rho}$ receptors (Amin and Weiss, 1994) were coexpressed with $\alpha 7$ subunits, and the reversal potential for $\mathrm{GABA}_{\rho}$-mediated currents was determined from a voltage ramp $(-60$ to $+20 \mathrm{mV})$ in the presence and absence of GABA $(1 \mu \mathrm{M})$. The mean reversal potential was estimated as $-26 \pm 2 \mathrm{mV}(n=5)$, which should reflect $\mathrm{E}_{\mathrm{Cl}}$ because the $\mathrm{GABA}_{\rho}$ receptor fluxes only $\mathrm{Cl}^{-}$under these conditions (Cutting et al., 1991). In each oocyte, clamped at the $\mathrm{GABA}_{\rho}$ reversal potential determined for that cell, the application of genistein still caused potentiation of nicotine-induced $\alpha 7$ responses (data not shown). Together, these results suggest that the enhancement of $\mathrm{nAChR}$ responses results directly from potentiation of $\alpha 7$ receptor-mediated currents.

To test whether the genistein-induced modulation of $\alpha 7$ currents was specific to particular nAChRs, common heteromeric receptor subtypes, $\alpha 4 \beta 2$ and $\alpha 3 \beta 4$, were also expressed in oocytes. Genistein $(10 \mu \mathrm{M})$ had no effect on $\alpha 4 \beta 2$ receptors. It produced a small inhibition of $\alpha 3 \beta 4$ receptors (Fig. 3 ), as reported previously for putative $\alpha 3 \beta 4^{\star}$ receptors (the asterisk indicates other, unknown subunits) in autonomic neurons (Glushakov et al., 1999; Wang et al., 2004), implying that the potentiating effects attributable to interference with tyrosine phosphorylation, at least over this short time period, were specific for the $\alpha 7$ subunit.

\section{Native $\alpha 7$ subunit-containing receptors in the hippocampus are functionally regulated by tyrosine kinase inhibition}

Although the data above indicate that $\alpha 7 \mathrm{nAChRs}$ are amenable to modulation, it may be a peculiarity of Xenopus oocytes. In order for such a mechanism to have physiological relevance, it must be applicable to receptors in CNS tissue. The hippocampus is an ideal structure to examine this question, because $\alpha 7$ receptors are highly expressed in this region (Seguela et al., 1993). Whole-cell patch-clamp recordings were made from hippocampal interneurons in the stratum radiatum (Alkondon et al., 1997a; Jones and Yakel, 1997; Frazier et al., 1998a), in response to brief (50 ms) pressure applications of the $\alpha 7$-selective agonist choline (10 mM) (Papke et al., 1996; Alkondon et al., 1997b). Choline-induced fast-activated inward currents in the majority of interneurons tested (Fig. 4A). The $\alpha 7$ responses showed a $10-20 \%$ "rundown" over the course of a 30 min experiment (Fig. $4 B$, open symbols) (Alkondon et al., 1994). However, superimposed on the rundown was $\mathrm{a} \approx 20-40 \%$ potentiation when 10 $\mu \mathrm{M}$ genistein was included in the perfusion media (Fig. $4 \mathrm{~B}$ ). The effects of genistein were reversible (Fig. $4 C$ ). Thus, although the potentiation was smaller than that observed in oocytes, it was qualitatively similar, implying that tyrosine kinase inhibition can augment native $\alpha 7 \mathrm{nAChR}$ responses. Likewise, in the presence of pervanadate $(10 \mu \mathrm{M})$, choline-induced currents were reduced by $\approx 30-40 \%$ compared with control (Fig. $4 A, B$ ). 


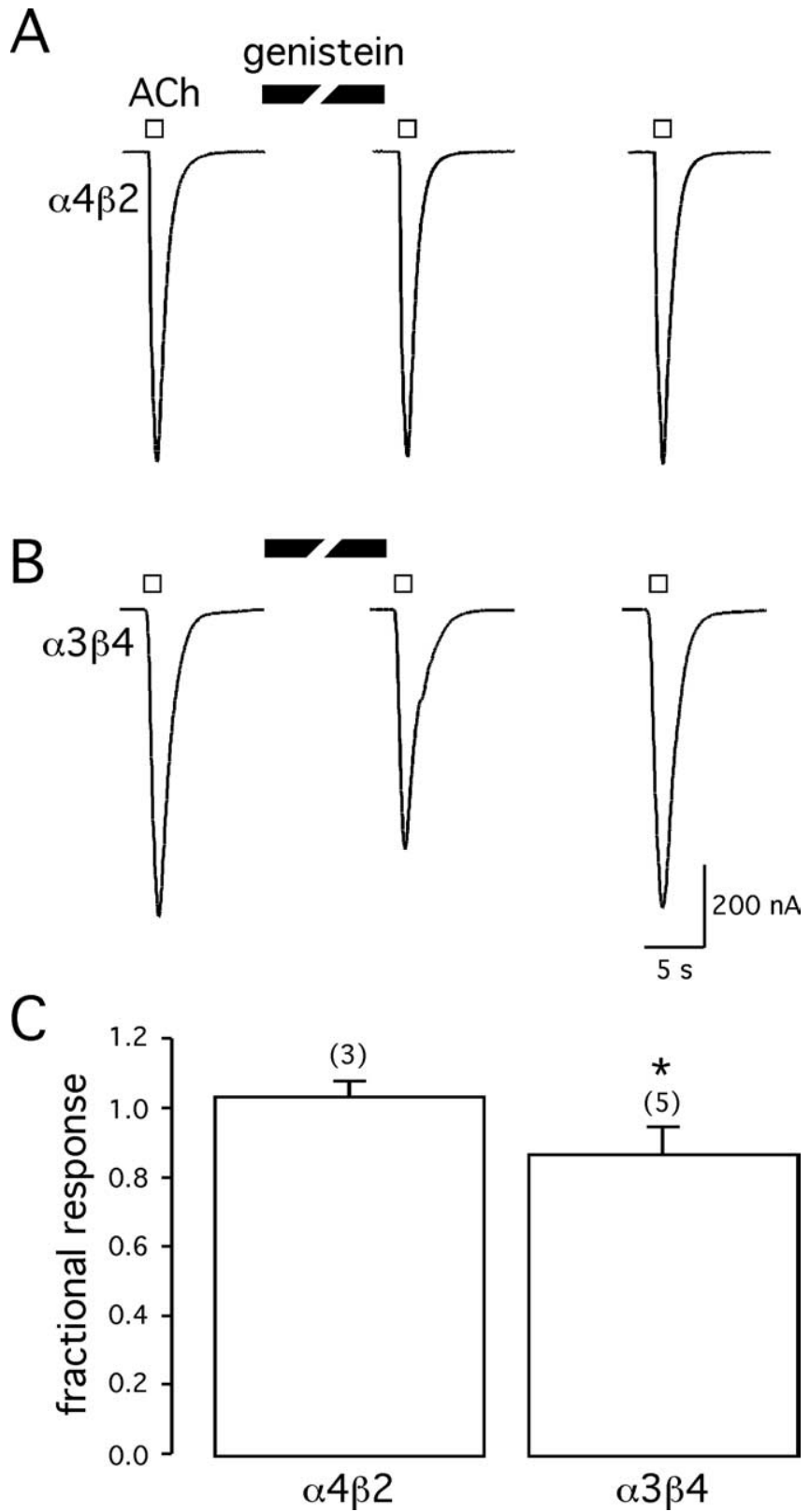

Figure 3. The action of genistein is specific to $\alpha 7 \mathrm{nAChRs}$. The effects of genistein (10 $\mu \mathrm{m})$ treatment on ACh-induced currents in oocytes expressing either $\alpha 4 \beta 2$ (A) or $\alpha 3 \beta 4$ (B) receptors are shown. $\boldsymbol{C}$, Histogram of the mean effects of genistein on these two classes of receptors.

Upregulation is associated with a change in the maximal $\alpha 7$ response

As a first approximation in determining the nature of the change in $\alpha 7 \mathrm{nAChRs,} \mathrm{ACh} \mathrm{concentration-response} \mathrm{curves} \mathrm{were} \mathrm{con-}$ structed in the presence and absence of genistein $(10 \mu \mathrm{M})$. Genistein caused potentiation across a wide range of agonist concentrations (Fig. 5). In particular, potentiation was evident at near-maximal concentrations of agonist (1.3-fold extrapolated from the fitted data), with an associated small, albeit significant, decrease in the $\mathrm{EC}_{50}$ value (Fig. $5 \mathrm{~A}$ ). Although changes in concentration-response curves are notoriously difficult to interpret in terms of receptor mechanism (Colquhoun, 1998), and notwithstanding underestimation of true peak $\alpha 7$ responses because of slow agonist exchange (Papke and Thinschmidt, 1998), the increase in the maximal response is consistent with the hypothe-
A

genistein $10 \mu \mathrm{M}$
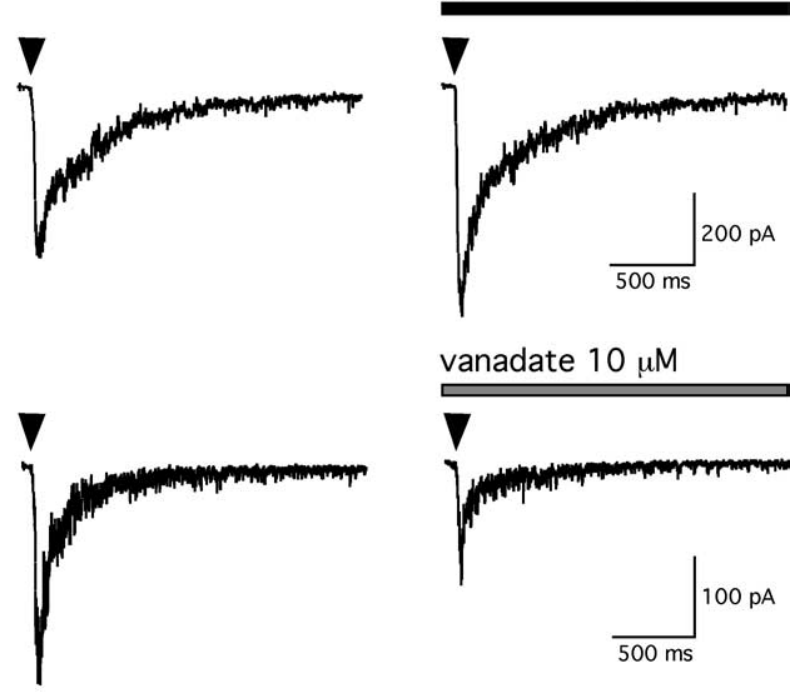

vanadate $10 \mu \mathrm{M}$

B

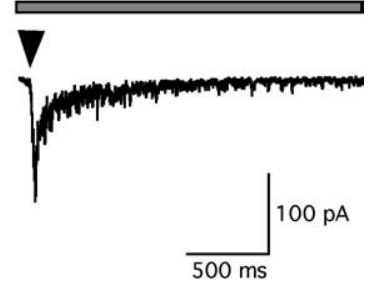

C
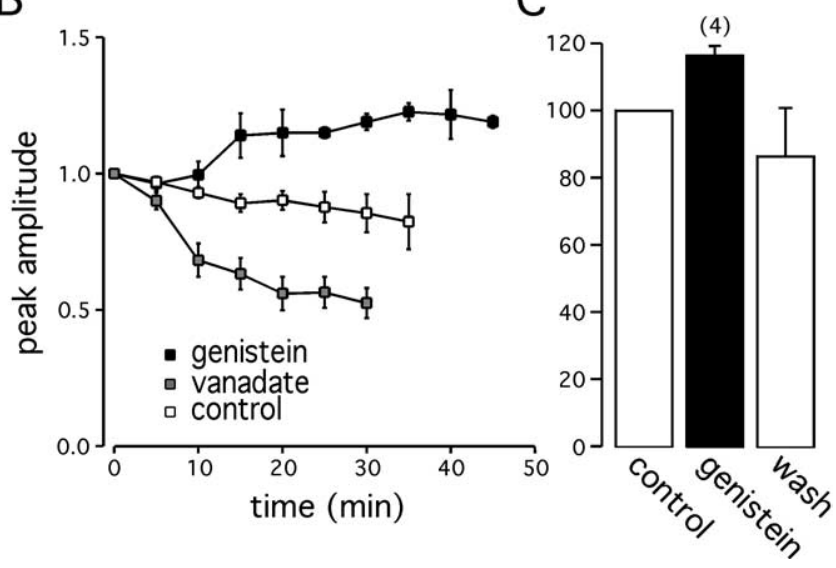

Figure 4. Native $\alpha 7 \mathrm{nAChRs}$ are regulated by tyrosine kinases and phosphatases. $A$, Example traces showing responses of hippocampal stratum radiatum interneurons to local pressure application of choline $(10 \mathrm{~mm})$, before and during administration of $10 \mu \mathrm{m}$ genistein (top) or 10 $\mu \mathrm{m}$ pervanadate. $\boldsymbol{B}$, Time course of the effects of genistein and pervanadate on choline-induced peak currents. Drugs were administered continuously via the bath starting at $t=0 \mathrm{~min}$. In the control condition (open symbols), slices were superfused with control ACSF only. C, Histogram illustrating the reversibility of a $5 \mathrm{~min}$ application of genistein in a separate series of experiments. The holding potential of neurons was $-70 \mathrm{mV}$.

sis that genistein causes potentiation through changes in either the number and/or properties (i.e., single-channel conductance, open probability) of the receptor.

Parallel changes in surface receptor number accompany the functional potentiation of $\alpha 7 \mathrm{nAChRs}$

Two experiments were conducted to test whether an increase in $\alpha 7$ receptor number could underlie the increase in $\alpha 7$ receptor function. The first approach was to examine the relative amount of surface-specific protein expression. To verify that we could detect specific $\alpha 7$ immunoreactivity, protein extracts from oocytes expressing nAChRs were subjected to immunoblotting under various conditions (Fig. 6A). An immunoreactive band of $\sim 55 \mathrm{kDa}$ was present in extracts immunoblotted with anti- $\alpha 7$ receptor antibody. No immunoreactivity was detected when the primary antibody was omitted in oocytes expressing $\alpha 4 \beta 2$ receptors or when the $\alpha 7$ antibody was preadsorbed with an $\alpha 7$ blocking peptide. This $\alpha 7$ antibody was then used in surface biotinyla- 


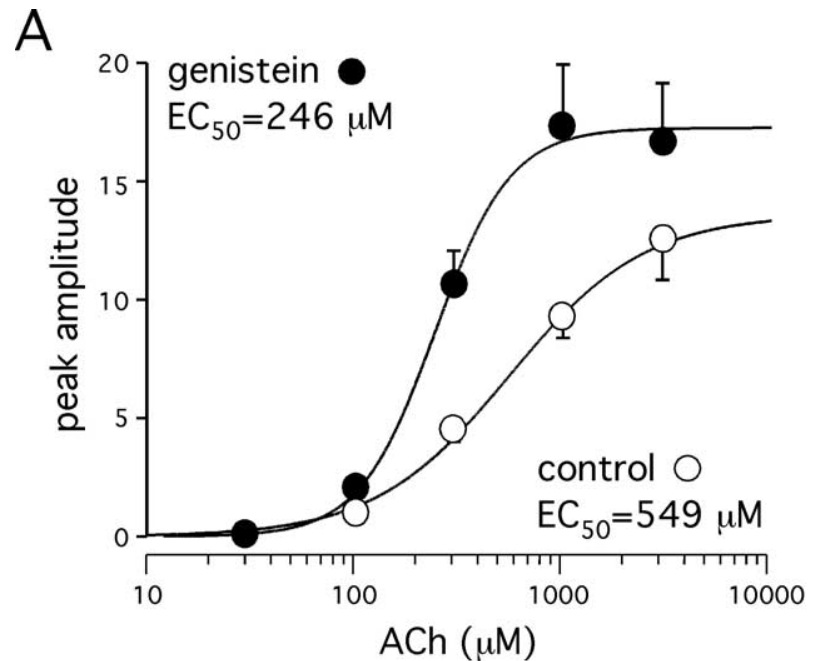

B

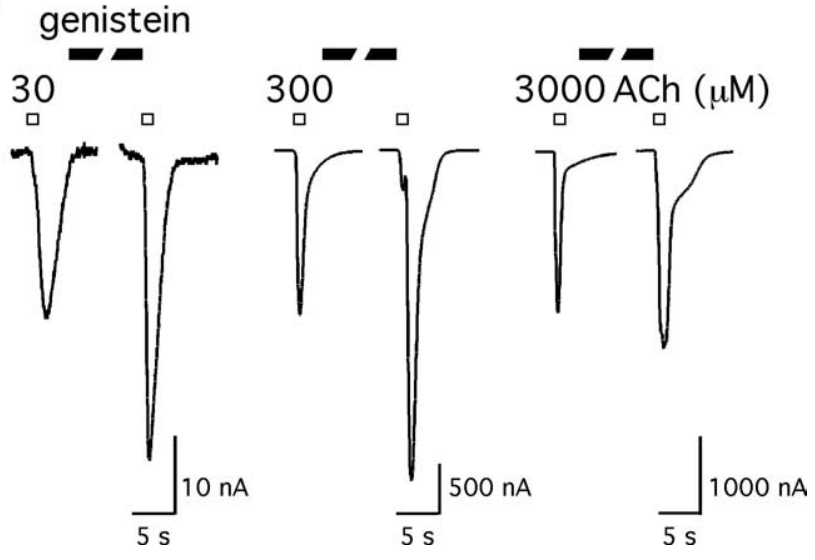

Figure 5. A, Concentration-response curves for ACh before and after treatment with $10 \mu \mathrm{M}$ genistein. All data points were normalized to the response induced by $100 \mu \mathrm{m}$ ACh alone. $\boldsymbol{B}$, Representative traces showing that genistein-mediated potentiation was present over a wide range of ACh concentrations $(30-3000 \mu \mathrm{m})$. Responses at concentrations of 30 and $300 \mu \mathrm{m}$ ACh were from the same oocyte, whereas those at $3 \mathrm{~mm} \mathrm{ACh}$ were from a different cell.

tion experiments. Under control conditions, in untreated oocytes expressing $\alpha 7$ receptors for $5 \mathrm{~d}$, there were approximately equal numbers of both nonbiotinylated and biotinylated $\alpha 7$ populations, implying that $\sim 50 \%$ of $\alpha 7$ protein is found on the cell surface (Fig. $6 B$ ). Two control experiments supported these findings: (1) the intracellular cytoskeletal protein actin was not labeled by the impermeant biotinylating reagent, suggesting that only surface proteins were being labeled; (2) immunoreactive bands were not seen in uninjected oocytes immunoblotted with $\alpha 7$ antibody (data not shown). However, in the presence of genistein $(10 \mu \mathrm{M})$, there was an increase in the biotinylated fraction and an associated decrease in the nonbiotinylated fraction, consistent with the idea that genistein increases the number of surface $\alpha 7 \mathrm{nAChRs}$ (Fig. $6 \mathrm{~B}$ ). Assuming that there is no change in the total number of receptors and that $\alpha 7$ subunits reflect fully assembled receptors (see below), these data imply that the actions of genistein result in the net redistribution of receptors from an intracellular pool to the surface. From comparison of the biotinylated fractions, in the presence and absence of genistein, the relative increase in plasma membrane $\alpha 7$ subunits was estimated at $60 \%$.

To confirm these findings and provide additional quantification, surface receptors were probed using $\left[{ }^{125} \mathrm{I}\right] \alpha \mathrm{BTX}$, a ligand
A

B
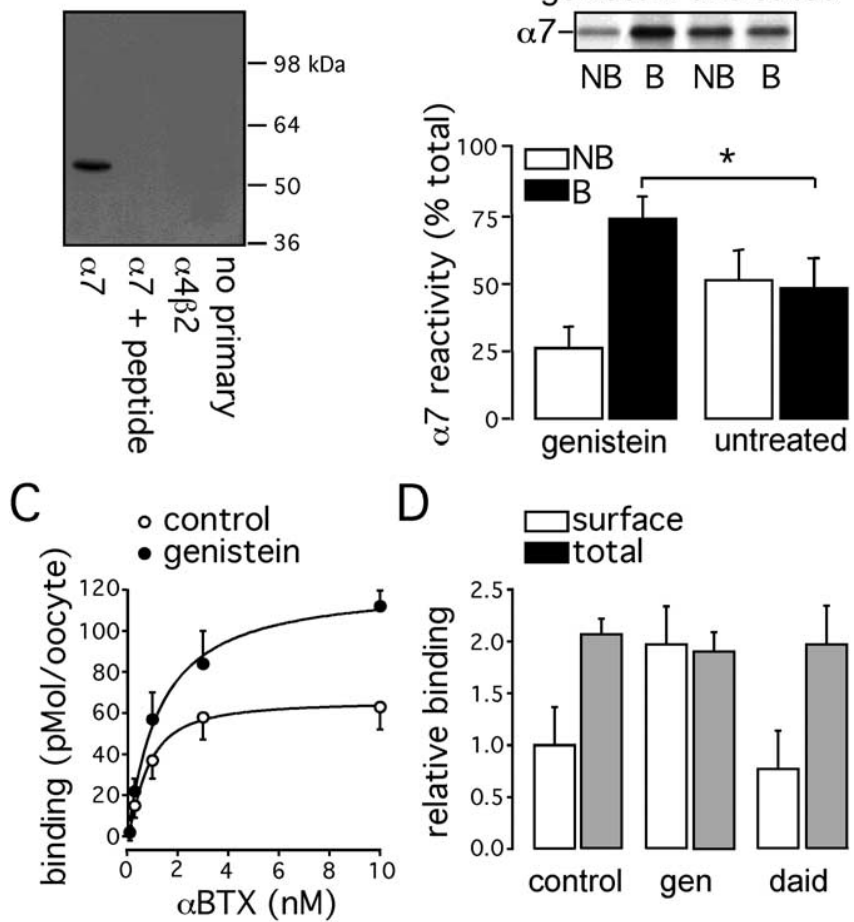

Figure 6. Surface expression of $\alpha 7$ receptors is increased by genistein. $\boldsymbol{A}, \alpha 7$ inmmunoreactivity in 00 cytes. Data are from 1000 cytes per lane. Immunoblotting conditions for each lane are listed below the gel. $\boldsymbol{B}$, The effects of genistein on nAChR surface expression. $\alpha 7$-expressing oocytes were left untreated or treated for 5 min before surface biotinylation with $10 \mu \mathrm{m}$ genistein. Representative immunoblot shows $\alpha 7$ immunoreactivity in surface biotinylated (B) and nonbiotinylated (NB) fractions. Data from three such experiments for biotinylated (filled bars) and nonbiotinylated (open bars) fractions are quantified in the graph from densitometry measurements and plotted relative to total $\alpha 7$ immunoreactivity. Experimental conditions that resulted in a significant change $(p<0.05)$ from control values are denoted by the asterisk. $\boldsymbol{C}$, Specific binding of $\alpha \mathrm{BTX}$ to the surface of intact oocytes ( $n=5$ per concentration) in the absence (open symbols) and presence (filled symbols) of $10 \mu \mathrm{m}$ genistein. Specific binding was obtained by subtracting background during competition with either ACh $(300 \mu \mathrm{m})$ or choline (10 mM). D, Specific $\alpha$ BTX binding to hippocampal cells showing both surface and total binding for each of three conditions: control, genistein (gen; $10 \mu \mathrm{M}$ ), daidzein (daid; $10 \mu \mathrm{M}$ ).

that only binds to correctly assembled and functional $\alpha 7 \mathrm{nAChRs}$ (Rakhilin et al., 1999). Specific $\left[{ }^{125} \mathrm{I}\right] \alpha \mathrm{BTX}$ binding to intact oocytes was measured across a range of ligand concentrations in the presence and absence of genistein $(10 \mu \mathrm{M})$. Genistein increased maximal surface binding $\left(B_{\max }\right)$ by $86 \%$, with an insignificant increase in the $\mathrm{EC}_{50}$ value for binding from 0.8 to $1.2 \mathrm{~nm}$ (Fig. $6 C)$. Together, the results of the biotinylation and the binding experiments provide evidence that the twofold functional upregulation of $\alpha 7 \mathrm{nAChRs}$ can be mostly, if not totally, accounted for by an increase in the number of surface receptors. Finally, the possibility that an alteration in surface receptor number underlies the potentiation of choline-mediated currents in hippocampal neurons (Fig. 4) was explored using $\left[{ }^{125} \mathrm{I}\right] \alpha \mathrm{BTX}$ binding to hippocampal neuron primary cultures. The results from these experiments show that genistein, but not the inactive analog daidzein, increased the fraction of receptors on the cell surface without changing the total number of receptors (Fig. 6D), implying that the mechanism of receptor regulation involves a true movement of receptors between intracellular and surface pools. Indeed, with equal distribution of receptors under control conditions, the twofold increase represents a complete shift of $\left[{ }^{125} \mathrm{I}\right] \alpha \mathrm{BTX}$-binding sites to the plasma membrane. 


\section{Genistein treatment does not alter the open probability of} $\alpha 7$ nAChRs

Although the observed increase in the number of surface receptors can fully account for changes in the absolute amplitude of $\alpha 7$ receptor-mediated currents, it does not explain the apparent shift in the $\mathrm{EC}_{50}$ value (Fig. 4). Increases in both agonist affinity (binding) and/or efficacy (gating) could underlie the decrease in the $\mathrm{EC}_{50}$ value (Colquhoun, 1998). Changes in either binding and/or gating would result in an increase in the open probability of the channel at a given nonsaturating concentration of agonist. Thus, experiments were designed to estimate changes in channel open probability using the open $\mathrm{nAChR}$ channel blocker chlorisondamine (Neely and Lingle, 1986). The most straightforward prediction is that, if potentiation results from an increase in open probability, then the chlorisondamine block should be greater in the presence compared with the absence of genistein at a constant agonist concentration. Stable responses were obtained at $5 \mathrm{~min}$ intervals using a low concentration of ACh $(30 \mu \mathrm{M})$; then, ACh and chlorisondamine $(5 \mu \mathrm{M})$ were coapplied, during which successive currents declined in a use-dependent manner (Fig. 7A). The extent of channel block was estimated from the ratio of the ACh responses immediately before and after the chlorisondamine treatment (blocking index). The data reveal that both the development and the extent of block by chlorisondamine were equal under these two conditions (Fig. $7 A, B$ ), implying that the augmentation of $\alpha 7$ currents by genistein does not involve a measurable change in open probability using this type of assay. To demonstrate that chlorisondamine would be able to detect such changes, it was also examined under conditions that are known to alter channel open probability (i.e., at different concentrations of agonist). In this case, chlorisondamine-induced block was greater at $300 \mu \mathrm{M}$ compared with $30 \mu \mathrm{M}$ ACh, as would be expected for the increase in open-channel probability at the higher agonist concentration (Fig. 7C).

Increased expression of $\alpha 7$ receptors is driven by exocytosis Assuming that the genistein-induced functional potentiation of $\alpha 7$ receptors results from additional receptors on the plasma membrane, then the rapid time course of this process (Fig. 2A) limits the mechanisms through which it could occur (e.g., protein synthesis or receptor assembly). Moreover, our data support the hypothesis that it involves trafficking of functional $\alpha$ BTX-labeled nAChRs between intracellular and surface pools (Fig. 6). It was reasoned that an increased number of $\alpha 7 \mathrm{nAChRs}$ on the plasma membrane could result from either a decreased rate of turnover (endocytosis) or an increase in the delivery of nAChRscontaining vesicles to the membrane (exocytosis).

To test whether inhibition of tyrosine kinase activity can decrease the rate of endocytosis of $\alpha 7$ nAChRs, the classical clathrin-mediated pathway was examined (Brodin et al., 2000). This pathway can be disrupted by the dominant-negative mutant of dynamin, dynamin K44A (McNiven et al., 2000). As a control, the CFTR channel, known to be regulated by changes in endocytosis (Bradbury et al., 1999), was coexpressed with either wildtype dynamin or dynamin K44A in oocytes. Consistent with previous studies, the basal expression of CFTR channels, assessed using a cAMP mixture ( $1 \mathrm{~mm}$ IBMX, $20 \mu \mathrm{M}$ forskolin, and $100 \mu \mathrm{M}$ dibutyryl-cAMP), was significantly larger in the presence of dynamin K44A compared with wild-type dynamin (Fig. 8A,B). However, unlike CFTR, the basal expression of nAChRs was not appreciably altered when $\alpha 7$ subunits were coexpressed with K44A dynamin (Fig. 8C). Moreover, their potentiation by genistein was also unaffected in the presence of either wild-type
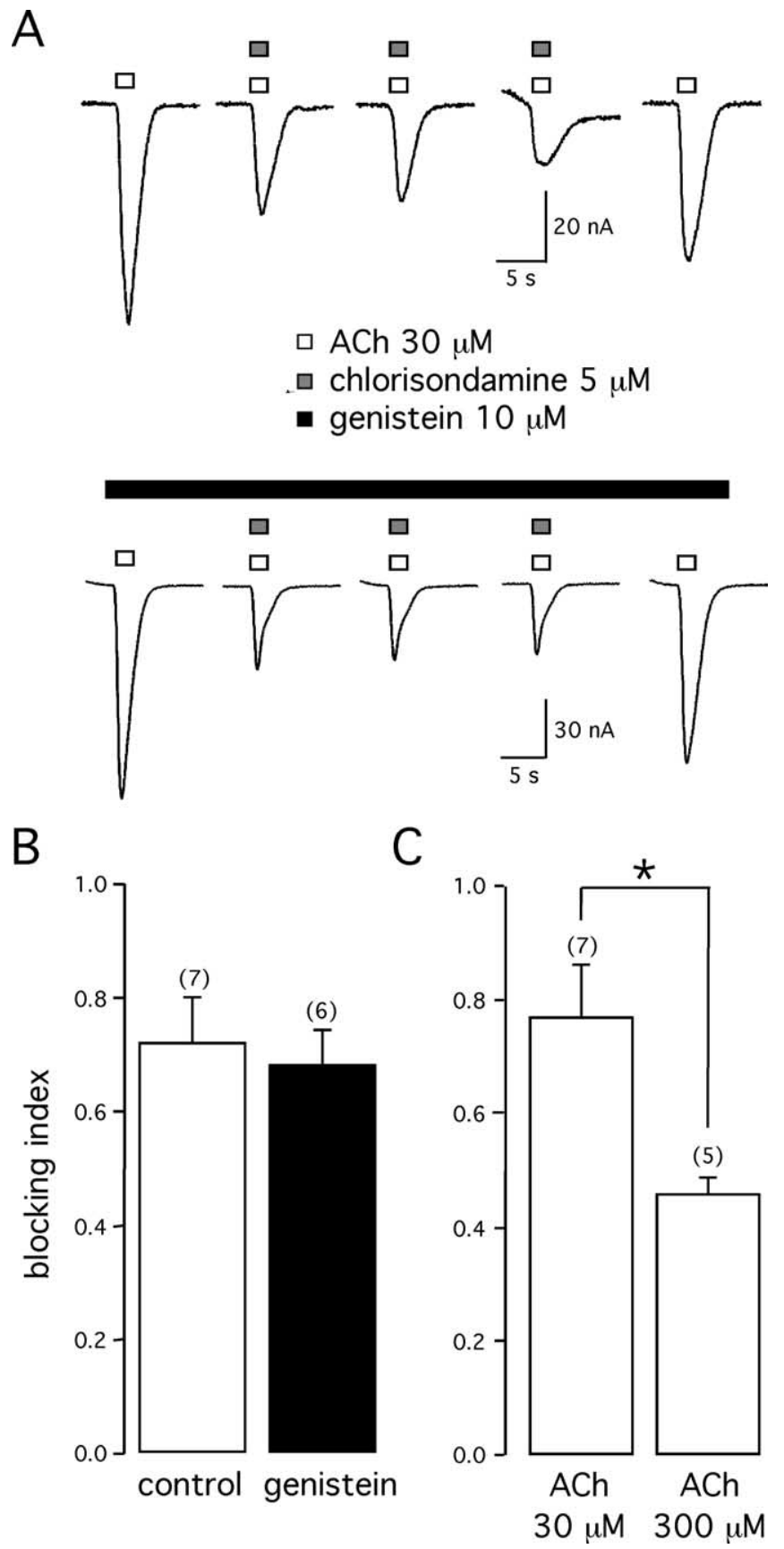

Figure 7. The open probability of $\alpha 7 \mathrm{nAChRs}$ is not affected by tyrosine kinase inhibition. $\boldsymbol{A}$, Examples showing the inhibition of $\alpha 7$ responses during coapplication of $\mathrm{ACh}(30 \mu \mathrm{m})$ and chlorisondamine $(5 \mu \mathrm{m})$ in the absence (top traces) or continuous presence (bottom traces) of $10 \mu \mathrm{m}$ genistein. The mean ratio of the $\mathrm{ACh}$-induced response immediately after coapplication compared with the response before coapplication with chlorisondamine (blocking index) is plotted as a function of the ACh concentration in the histogram $(\boldsymbol{B})$. $\boldsymbol{C}$, Test of the usefulness of chlorisondamine to detect changes in open probability. The difference in the blocking index resulting from coapplication of both 30 and $300 \mu \mathrm{m} \mathrm{ACh}$ and $5 \mu \mathrm{m}$ chlorisondamine is plotted as a histogram.

or mutant dynamin (Fig. $8 D$ ). These data are consistent with other studies showing that $\alpha 7$ receptors do not undergo rapid endocytosis (Drisdel et al., 2004). Additional experiments were performed because $\alpha 7 \mathrm{nAChRs}$ are found within membrane lipid rafts and thus may be internalized independent of dynamin (Bruses et al., 2001). Specifically, it was tested whether methyl- $\beta$ cyclodextrin $(\mathrm{M} \beta \mathrm{C})$, which disrupts these rafts by extracting cho- 
A

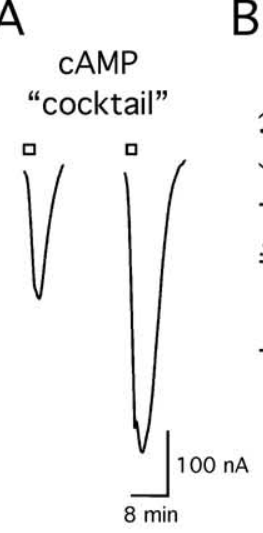

B

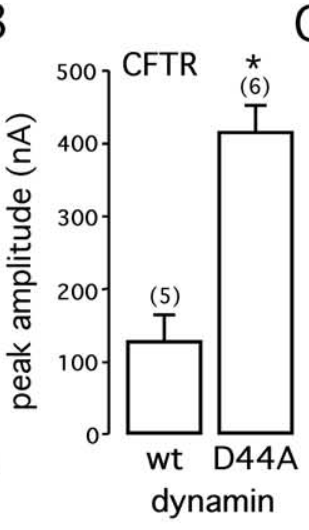

C

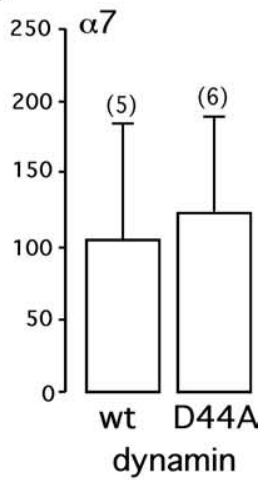

D
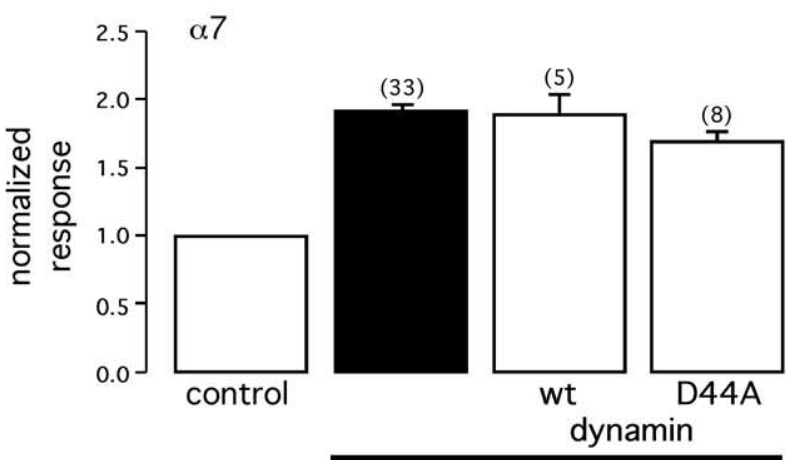

genistein

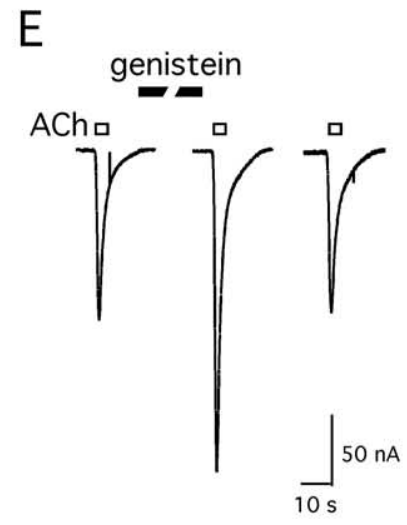

$\mathrm{F}$
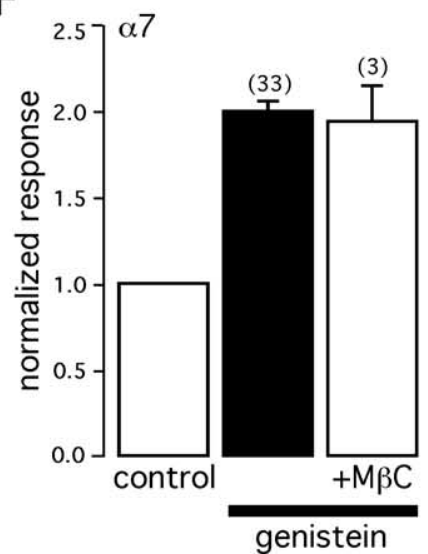

Figure 8. Endocytosis is not involved in upregulation of $\alpha 7$ receptors. $\boldsymbol{A}$, Representative currents induced by application of a CAMP agonist mixture for 2 min in oocytes coexpressing CFTR with either wild-type (wt) or K44A dynamin. The holding potential was $-50 \mathrm{mV}$. B, Histogram of the mean CFTR-mediated currents induced by the CAMP agonist mixture. $C$, Histogram of the mean currents induced by $\mathrm{ACh}(100 \mu \mathrm{m})$ in oocytes coexpressing $\alpha 7 \mathrm{nAChRs}$ with either wild-type or K44A dynamin. The holding potential was $-65 \mathrm{mV}$. D, Histogram showing the effect of genistein $(10 \mu \mathrm{M})$ on $\alpha 7$ receptor-mediated responses in oocytes expressing either wild-type or K44A dynamin. $\boldsymbol{E}$, Representative examples of the genistein-mediated potentiation of $\alpha 7$ currents after $M \beta$ C pretreatment ( $10 \mu \mathrm{m} ; 60-90 \mathrm{~min}$ ). F, Histogram illustrating the effects of $M \beta C$ pretreatment.

lesterol, could interfere with the potentiation. However, similar to dynamin $\mathrm{K} 44 \mathrm{~A}, \mathrm{M} \beta \mathrm{C}$ had no effect on genistein-induced $\alpha 7$ currents (Fig. 8E,F). Together, these observations demonstrate that the functional enhancement of $\alpha 7 \mathrm{nAChRs}$ does not occur by slowing their rate of removal from the plasma membrane.

Regulated exocytosis is a common pathway that many cells

A

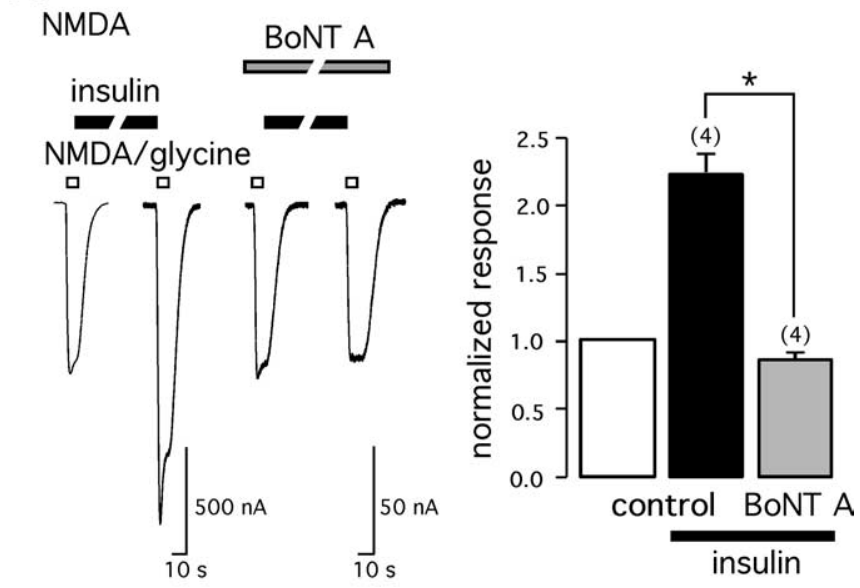

B

$\mathrm{C}_{\alpha 7}$

D
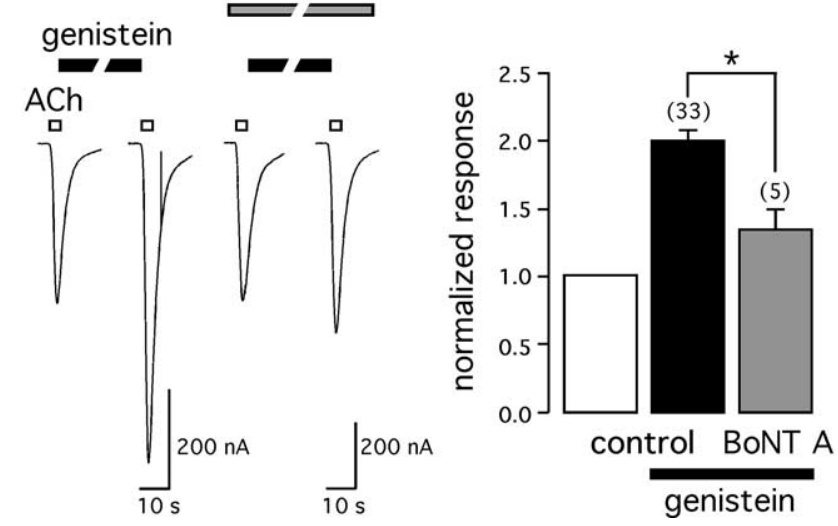

Figure 9. SNARE-mediated exocytosis is involved in the augmentation of $\alpha 7 \mathrm{nAChRs}$ by genistein. $A$, Examples of currents induced by the coagonists NMDA (300 $\mu \mathrm{M})$ and glycine (10 $\mu \mathrm{M})$ in oocytes expressing NR1a and NR2b subunits before and after exposure to insulin ( $5 \mu \mathrm{M}$; $10 \mathrm{~min}$ ) 5-7 h after injection of vehicle (control; left two traces) or with $50 \mathrm{ng}$ of BoNT-A (right two traces). $\boldsymbol{B}$, Histogram illustrating the effects of BoNT-A on the insulin-mediated potentiation of NMDA receptors. $C$, Examples of currents induced by $A C h(100 \mu \mathrm{m})$ in oocytes expressing $\alpha 7$ subunits before and after exposure to genistein $(10 \mu \mathrm{m} ; 5 \mathrm{~min}) 5-7 \mathrm{~h}$ after injection of vehicle (control; left two traces) or with $1 \mathrm{ng}$ of BoNT-A (right two traces). D, Histogram illustrating the effects of BoNT-A on the genistein-mediated potentiation of $\alpha 7 \mathrm{nAChRs}$.

use to rapidly deliver ligand-gated channels to the plasma membrane (Malinow and Malenka, 2002). To explore whether $\alpha 7$ receptors can be trafficked to the membrane using this pathway, oocytes were injected, 5-7 h before measurement, with BoNT-A (50 ng/oocyte), which cleaves the soluble $N$-ethylmaleimidesensitive factor attachment protein receptor (SNARE) protein SNAP25, thus preventing exocytosis (Montecucco and Schiavo, 1995). Control experiments were performed based on the known upregulation of NMDA receptors by insulin, a process dependent on SNARE-mediated exocytosis (Skeberdis et al., 2001). Figure 9 , $A$ and $B$, confirmed that the augmentation of NMDA receptor function by insulin $(5 \mu \mathrm{M} ; 10 \mathrm{~min})$ could be completely inhibited by BoNT-A pretreament. Likewise, the potentiation of $\alpha 7$ nAChR-mediated responses by genistein could be impaired by $\sim 70 \%$ in the presence of toxin (Fig. $9 C, D$ ). By showing that exocytosis is likely involved in the effects of genistein, these data provide strong support linking the functional upregulation of $\alpha 7$ receptors with the increased number of nAChRs on the cell surface. 
Protein kinases and phosphatases need to be in close proximity to receptors to effectively regulate function, and as such they are often colocalized through accessory proteins tethered to the actin cytoskeleton (Davis et al., 2001; Sheng, 2001). Moreover, breakdown of filamentous actin has known effects on $\alpha 7 \mathrm{nAChRs}$ (Liu and Berg, 1999). To test whether an intact cytoskeleton was necessary for the functional regulation of $\alpha 7 \mathrm{nAChRs}$, oocytes were pretreated (5-10 $\mathrm{min}$ ) with the actin depolymerizing agent cytochalasin D (cyt D; $10 \mu \mathrm{M}$ ) and then subsequently exposed to genistein in the continued presence of cyt D (Fig. 10). A 5-10 min treatment with cyt $\mathrm{D}$ reduced basal $\alpha 7$ receptor-mediated responses, as shown previously (Liu and Berg, 1999), but did not prevent the twofold potentiation by genistein. These data imply that the effects of tyrosine kinase inhibition are likely independent of the cytoskeleton.

\section{Increased function does not require direct dephosphorylation of $\alpha 7$ subunits}

The large intracellular loop between transmembrane domains 3 and 4 of rat $\alpha 7$ subunits contains three tyrosine residues. One mechanism through which the number and function of surface $\alpha 7$ receptors could be augmented is via direct dephosphorylation of one or more of these residues. If this was the case, then elimination of these residues should produce an $\alpha 7$ receptor on the cell surface that is already maximally effective and incapable of further enhancement through genistein treatment. A series of mutant $\alpha 7$ receptors was generated in which each of the tyrosine residues was changed to a phenylalanine, either individually or together (triple mutant). All of these $\alpha 7$ constructs were functionally expressed in oocytes and assessed for sensitivity to genistein. In all cases, genistein treatement led to enhancement of nicotinic responses that was of a similar magnitude to wild-type $\alpha 7$ nAChRs (Fig. 11). These observations imply that dephosphorylation of the $\alpha 7$ subunit is not a necessary step in the potentiation of receptor function and that other steps involving tyrosine dephosphorylation of intermediate proteins are required.

\section{Discussion}

Many types of ion channels are functionally modified by tyrosine phosphorylation (Davis et al., 2001). Here, it is reported that the ligand-gated $\alpha 7 \mathrm{nAChR}$ is susceptible to regulation through PTKs and PTPs. The evidence is based on the following findings: (1) that the PTK inhibitor genistein specifically and rapidly causes a functional upregulation of $\alpha 7 \mathrm{nAChRs} \mathrm{expressed} \mathrm{heter-}$ ologously in Xenopus oocytes and natively in hippocampal interneurons; and (2) that either stimulation of the insulin receptor, a membrane PTK, or inhibition of PTPs by pervanadate depresses $\alpha 7$ receptor function. These data imply that the function of $\alpha 7$ $\mathrm{nAChRs}$ is augmented under conditions favoring protein tyrosine dephosphorylation. The increase in $\alpha 7$ function was accompanied by an increase in the number of $\alpha 7$ subunits/ $\alpha$ BTXbinding sites on the plasma membrane and a concomitant decrease in the intracellular receptor pool, consistent with the idea that tyrosine phosphorylation can regulate the steady-state surface distribution. Altered trafficking of receptors to the membrane through SNARE-mediated exocytosis may essentially explain the increase.

Modes of $\boldsymbol{\alpha} 7 \mathrm{nAChR}$ regulation by tyrosine phosphorylation To effect a change in the maximal response generated by a population of ion channels (Fig. 4), one or more of three factors controlling channel activity must be altered: (1) the total number of functional channels $(n) ;(2)$ the receptor open probability $\left(P_{\mathrm{o}}\right)$;
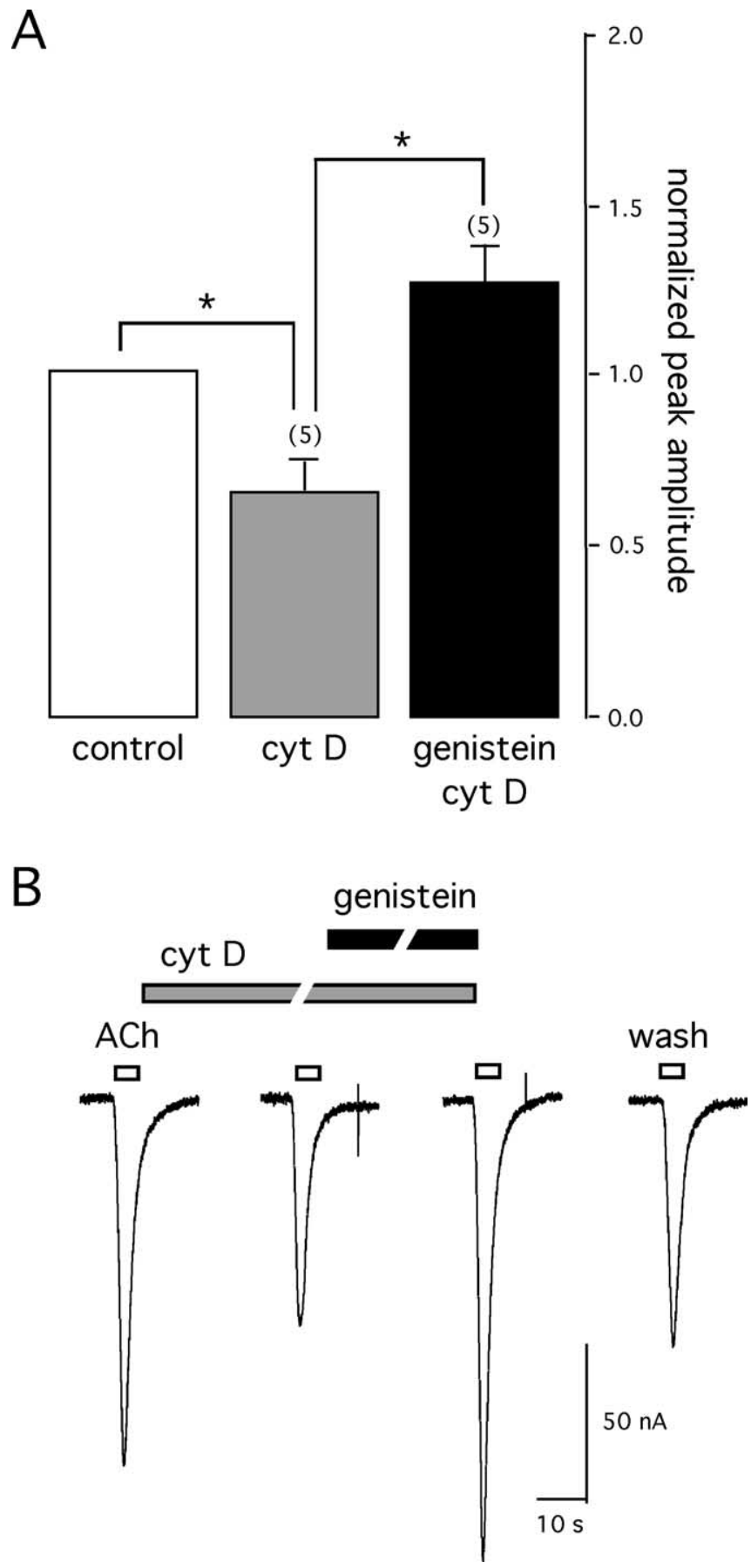

Figure 10. The actin cytoskeleton is not involved in the genistein-induced regulation of $\alpha 7$ nAChRs. $\boldsymbol{A}$, Histogram showing the mean effects of cyt $D$ pretreament on genistein-induced potentiation of $\alpha 7$ receptor-mediated responses. $B$, Examples traces of $\alpha 7$ receptor-mediated currents induced by $A C h(100 \mu \mathrm{M})$ in control medium 5-10 min after cyt D (10 $\mu \mathrm{M})$ treatment, 5 min after coapplication of cyt $D$ and genistein $(10 \mu \mathrm{m})$, and after wash.

or (3) the single-channel conductance $(i)$. The overall whole-cell response $(I)$ is determined by their product (Belardetti and Sieglebaum, 1988); hence, $I=n P_{\mathrm{o}} i$ (Eq. 1). In the current study, we explicitly assessed the contribution of both $n$ and $P_{\mathrm{o}}$, inferring any change in $i$ from Equation 1.

The relative fraction of surface channels was estimated from two independent assays, biotinylation/immunoblotting and radiolabeled binding. Results from both sets of experiments are consistent with the suggestion that genistein treatment causes an 


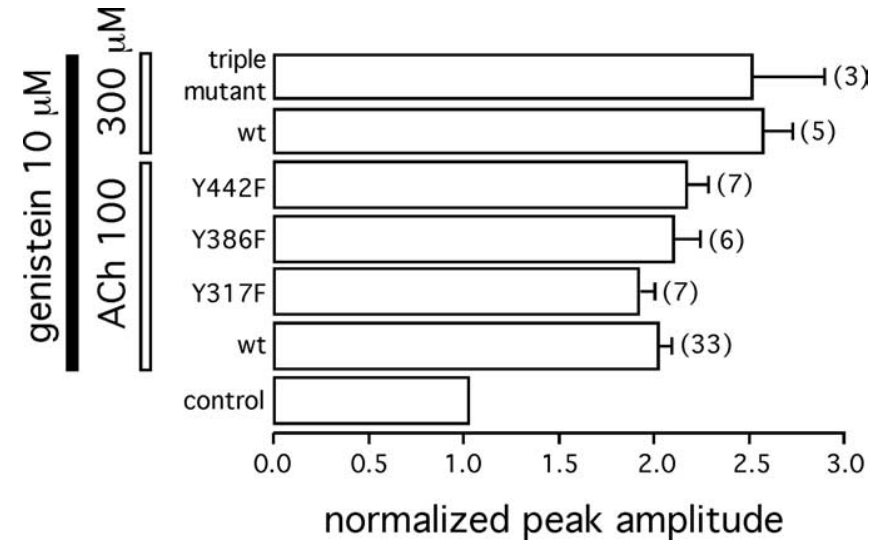

Figure 11. The effects of genistein do not involve tyrosine residues on $\alpha 7$ subunits. A histogram comparing the potentiation by genistein $(10 \mu \mathrm{m})$ of mutant $\alpha 7$ subunits to wild-type $\alpha 7$ subunits is shown. Mutant subunits contained either a single point mutation at each of the three tyrosine residues (Y317, Y386, and Y442) or a triple mutation of all three residues (triple mutant). Each subunit, mutants and wild type, were expressed separately in oocytes and tested after a 5 min incubation with genistein.

increase in the number of plasma membrane $\alpha 7 \mathrm{nAChRs,} \mathrm{with}$ the $\alpha$ BTX-binding studies providing quantitative evidence that the change in $n$ is sufficient to account for the twofold change in function. Although there is no direct support that the change in response amplitude is attributable to the "new" surface nAChRs, it is reassuring to note that disruption of vesicle exocytosis (presumably the supply of the new nAChRs) essentially ( $\approx 70 \%$ ) prevented the functional change. However, it is difficult to eliminate the possibility that (some of) the increased response results from the conversion of nonfunctional to functional preexisting surface $\alpha 7$ nAChRs, as proposed for other nAChRs (Margiotta et al., 1987). In addition, it is not possible to dismiss alterations in $\alpha 7$ nAChR properties $\left(P_{\mathrm{o}}\right.$ and $\left.i\right)$. First, the small but significant decrease in the $\mathrm{EC}_{50}$ value, if not compromised by receptor desensitization, implies a change in $P_{\mathrm{o}}$. This could be reflected by increased agonist binding affinity and/or channel gating, processes that are difficult to separate experimentally (Colquhoun, 1998). The lack of a genistein-induced change in inhibition attributable to the open-channel blocker chlorisondamine implies that an increase in $P_{\mathrm{o}}$ does not underlie $\alpha 7$ receptor modulation, although our chlorisondamine assay may not be sensitive enough to detect small changes in $P_{\mathrm{o}}$. Finally, although an increase in $i$ could contribute to increased function, this seems unlikely for two reasons. First, there have been no reports of modulation of this receptor property (Du and Role, 2001; Conroy et al., 2003). Second, when regulation of function occurs, it is often accompanied by parallel changes in number (e.g., nicotine-induced changes in the functional density of $\alpha 7$ currents in neurons can be accounted for by altered surface receptor number) (Molinari et al., 1998; Kawai and Berg, 2001; Liu et al., 2001). Extrapolating the results from the oocyte expression system to hippocampal neurons is not as straightforward, because although the data are generally consistent, the twofold change in surface $\alpha \mathrm{BTX}$ sites is not mirrored by an equivalent change in function.

\section{Cellular mechanisms of $\alpha 7 \mathrm{nAChR}$ regulation}

Long-term treatment of neuronal cells with ligands for receptor PTKs (neuregulins, brain-derived neurotrophic factor) can enhance both the number ( $\alpha \mathrm{BTX}$-binding sites/clusters) and function of $\alpha 7 \mathrm{nAChRs}$ in hippocampal cells (Liu et al., 2001; Kawai et al., 2002). A cytosine-rich form of neuregulin causes changes in
nAChR subunit mRNAs and channel function, including $\alpha 7$, in sympathetic neurons (Yang et al., 1998). Collectively, these data argue that PTK activation enhances the expression of functional $\alpha 7$ receptors, possibly through mechanisms involving gene transcription. Our data contrast with these results in two ways: (1) PTK inhibition, not activation, causes upregulation of these channels; and (2) the effects are both rapid and transient.

Studies on other types of receptors, however, demonstrate multiple modes of tyrosine phosphorylation-dependent regulation. NMDA receptors are upregulated rapidly by stimulation of both receptor and nonreceptor PTKs (Wang and Salter, 1994; Liu et al., 1995; Chen and Leonard, 1996; Kohr and Seeburg, 1996). Conversely, and similar to results reported here, tyrosine phosphorylation of structurally related $\mathrm{GABA}_{\mathrm{A}}$ receptors can lead to a transient functional inhibition (Castel et al., 2000), implying that PTK activation may exert differential forms of receptor regulation. For NMDA receptors, the tyrosine phosphorylationinduced signaling pathway ultimately results in the SNAREmediated exocytotic delivery of receptors to the surface (Skeberdis et al., 2001). The cellular processes that control the number of functional membrane $\alpha 7 \mathrm{nAChRs}$ are not fully understood. The normal delivery of $\alpha 7$ receptors from intracellular pools to the surface is clearly an important but not well defined process (Dineley and Patrick, 2000), and it is likely that, at least for this nAChR subtype, trafficking may depend on neuronspecific factors involved in the membrane targeting of proteins (Kassner and Berg, 1997; Sweileh et al., 2000). Indeed, during assembly in the endoplasmic reticulum, palmitoylation at cysteine residues in the intracellular loop of the $\alpha 7$ subunit is critical for surface receptor expression and fails to occur in certain nonneuronal cells (Drisdel et al., 2004). Unlike the current results in hippocampal neurons, Kawai and Berg (2001) did not find evidence for an extensive intracellular reserve of $\alpha 7 \mathrm{nAChRs}$ in cortical cells, and nicotine-induced upregulation of surface receptors required de novo synthesis of nAChRs. Regardless of the exact nature of regulation, receptors are most likely delivered to the plasma membrane via vesicular exocytosis.

In the present study, given that interference with SNAREmediated vesicle fusion, but not endocytosis, mostly prevented the genistein-mediated increase in functional $\alpha 7 \mathrm{nAChRs,} \mathrm{it} \mathrm{is}$ concluded that pharmacological manipulation of PTKs and PTPs specifically alters the net rate of exocytosis of $\alpha 7$ nAChRcontaining vesicles. Furthermore, because the effects are rapid and reversible, such an interpretation implies a constitutive and modifiable recycling of receptors between intracellular and surface pools. A dynamic cycling of $\alpha 7 \mathrm{nAChRs}$ has not yet been described and seems incompatible with the relatively slow turnover rate of these receptors, at least in PC12 cells (Drisdel et al., 2004). Likewise in the present study, the basal expression of $\alpha 7$ nAChRs is insensitive to impairment of the canonical endocytotic pathway, although it remains possible that after reversal of PTK inhibition, the newly inserted receptors are subject to a rapid endocytotic turnover. Interestingly, tyrosine phosphorylation of $\mathrm{K}^{+}$channels promotes internalization through an endocytotic mechanism, whereas, and similar to $\alpha 7$ nAChRs, tyrosine dephosphorylation facilitates their exocytotic delivery to the membrane (Sterling et al., 2002, 2003). As an alternative, the effects of PTK inhibition could operate independently of a slower basal cycling of nAChRs, perhaps by inducing the exocytosis of vesicles containing receptors that are not normally destined for the plasma membrane. A rapid and inducible exocytotic trafficking of $\alpha 7 \mathrm{nAChRs}$ may allow cholinergic synapses to experience rapid changes in transmission efficacy similar to changes in 
AMPA receptors at glutamatergic synapses (Sheng and Kim, 2002).

The observation that the effects of genistein on $\alpha 7 \mathrm{nAChRs}$ does not depend on dephosphorylation/phosphorylation of the $\alpha 7$ subunit per se implies that some other protein(s) is the target of the PTKs and PTPs. At the NMJ, despite strong evidence that muscle nAChR subunits can be phosphorylated at tyrosine residues, this is not necessary for agrin/rapsin-mediated clustering of receptors, a process that is directly associated with PTK activation (Qu et al., 1996; Meyer and Wallace, 1998). Likewise the insulinmediated increase surface NMDA receptors does not require tyrosine phosphorylation of NMDA subunits (Skeberdis et al., 2001), suggesting that PTK-dependent trafficking of a variety of receptors occurs via intermediate proteins (Balasubramanian and Huganir, 1999). Given the complexity of protein interactions during the process of vesicle exocytosis (Sudhof, 2004), there are many potential targets for tyrosine phosphorylation/dephosphorylation.

The finding that genistein-induced potentiation is restricted to $\alpha 7 \mathrm{nAChRs}$ is puzzling because exocytosis is likely to be a ubiquitous mechanism for delivery of receptors to the plasma membrane. However, as discussed above, the expression of $\alpha 7$ channels requires complex and probably specific posttranslational processing (Drisdel et al., 2004). In further support of a unique regulation of $\alpha 7 \mathrm{nAChRs}$, it has been shown recently that coexpression of the gene hRIC3 (resistant to inhibitors of cholinesterase) produces a twofold increase in $\alpha 7$ receptor function, while causing a downregulation of other nAChR subtypes (Halevi et al., 2003).

\section{References}

Akiyama T, Ishida J, Nakagawa S, Ogawara H, Watanabe S, Itoh N, Shibuya M, Fukami Y (1987) Genistein, a specific inhibitor of tyrosine-specific protein kinases. J Biol Chem 262:5592-5595.

Alkondon M, Reinhardt S, Lobron C, Hermsen B, Maelicke A, Albuquerque EX (1994) Diversity of nicotinic acetylcholine receptors in rat hippocampal neurons. II. The rundown and inward rectification of agonistelicited whole-cell currents and identification of receptor subunits by in situ hybridization. J Pharmacol Exp Ther 271:494-506.

Alkondon M, Pereira EF, Barbosa CT, Albuquerque EX (1997a) Neuronal nicotinic acetylcholine receptor activation modulates $\gamma$-aminobutyric acid release from CA1 neurons of rat hippocampal slices. J Pharmacol Exp Ther 283:1396-1411.

Alkondon M, Pereira EF, Cortes WS, Maelicke A, Albuquerque EX (1997b) Choline is a selective agonist of $\alpha 7$ nicotinic acetylcholine receptors in the rat brain neurons. Eur J Neurosci 9:2734-2742.

Amin J, Weiss DS (1994) Homomeric $\rho 1$ GABA channels: activation properties and domains. Receptors Channels 2:227-236.

Balasubramanian S, Huganir RL (1999) Characterization of phosphotyrosine containing proteins at the cholinergic synapse. FEBS Lett 446:95-102.

Barish ME (1983) A transient calcium-dependent chloride current in the immature Xenopus oocyte. J Physiol (Lond) 342:309-325.

Belardetti F, Siegelbaum SA (1988) Up-and down-modulation of single $\mathrm{K}^{+}$channel function by distinct second messengers. Trends Neurosci 11:232-238.

Bradbury NA, Clark JA, Watkins SC, Widnell CC, Smith HS, Bridges RJ (1999) Characterization of the internalization pathways for the cystic fibrosis transmembrane conductance regulator. Am J Physiol 276:L659-L668.

Brodin L, Low P, Shupliakov O (2000) Sequential steps in clathrinmediated synaptic vesicle endocytosis. Curr Opin Neurobiol 10:312-320.

Bruses JL, Chauvet N, Rutishauser U (2001) Membrane lipid rafts are necessary for the maintenance of the $\alpha 7$ nicotinic acetylcholine receptor in somatic spines of ciliary neurons. J Neurosci 21:504-512.

Castel H, Louiset E, Anouar Y, Le Foll F, Cazin L, Vaudry H (2000) Regulation of $\mathrm{GABA}_{\mathrm{A}}$ receptor by protein tyrosine kinases in frog pituitary melanotrophs. J Neuroendocrinol 12:41-52.

Chen S, Leonard JP (1996) Protein tyrosine kinase-mediated potentiation of currents from cloned NMDA receptors. J Neurochem 67:194-200.
Colquhoun D (1998) Binding, gating, affinity and efficacy: the interpretation of structure-activity relationships for agonists and of the effects of mutating receptors. Br J Pharmacol 125:924-947.

Conroy WG, Liu QS, Nai Q, Margiotta JF, Berg DK (2003) Potentiation of $\alpha 7$-containing nicotinic acetylcholine receptors by select albumins. Mol Pharmacol 63:419-428.

Cutting GR, Lu L, O’Hara BF, Kasch LM, Montrose-Rafizadeh C, Donovan DM, Shimada S, Antonarakis SE, Guggino WB, Uhl GR, Kazazian HH Jr (1991) Cloning of the $\gamma$-aminobutyric acid (GABA) rho 1 cDNA: a GABA receptor subunit highly expressed in the retina. Proc Natl Acad Sci USA 88:2673-2677.

Davis KE, Straff DJ, Weinstein EA, Bannerman PG, Correale DM, Rothstein JD, Robinson MB (1998) Multiple signaling pathways regulate cell surface expression and activity of the excitatory amino acid carrier 1 subtype of Glu transporter in C6 glioma. J Neurosci 18:2475-2585.

Davis MJ, Wu X, Nurkiewicz TR, Kawasaki J, Gui P, Hill MA, Wilson E (2001) Regulation of ion channels by protein tyrosine phosphorylation. Am J Physiol 281:H1835-H1862.

De Koninck P, Cooper E (1995) Differential regulation of neuronal nicotinic ACh receptor subunit genes in cultured neonatal rat sympathetic neurons: specific induction of $\alpha 7$ by membrane depolarization through a $\mathrm{Ca}^{2+} /$ calmodulin-dependent kinase pathway. J Neurosci 15:7966-7978.

Dineley KT, Patrick JW (2000) Amino acid determinants of $\alpha 7$ nicotinic acetylcholine receptor surface expression. J Biol Chem 275:13974-13985.

Drisdel RC, Manzana E, Green WN (2004) The role of palmitoylation in functional expression of nicotinic $\alpha 7$ receptors. J Neurosci 24:10502-10510.

Du C, Role LW (2001) Differential modulation of nicotinic acetylcholine receptor subtypes and synaptic transmission in chick sympathetic ganglia by $\mathrm{PGE}_{2}$. J Neurophysiol 85:2498-2508.

Eisele JL, Bertrand S, Galzi JL, Devillers-Thiery A, Changeux JP, Bertrand D (1993) Chimeric nicotinic-serotonergic receptor combines distinct ligand binding and channel specificities. Nature 366:479-483.

Fenster CP, Rains FM, Noerager B, Quick MW, Lester RAJ (1997) Influence of subunit composition on desensitization of neuronal acetylcholine receptors at low concentrations of nicotine. J Neurosci 17:5747-5759.

Fenster CP, Whitworth TL, Sheffield EB, Quick MW, Lester RA (1999) Upregulation of surface $\alpha 4 \beta 2$ nicotinic receptors is initiated by receptor desensitization after chronic exposure to nicotine. J Neurosci 19:4804-4814.

Frazier CJ, Rollins YD, Breese CR, Leonard S, Freedman R, Dunwiddie TV (1998a) Acetylcholine activates an $\alpha$-bungarotoxin-sensitive nicotinic current in rat hippocampal interneurons, but not pyramidal cells. J Neurosci 18:1187-1195.

Frazier CJ, Buhler AV, Weiner JL, Dunwiddie TV (1998b) Synaptic potentials mediated via $\alpha$-bungarotoxin-sensitive nicotinic acetylcholine receptors in rat hippocampal interneurons. J Neurosci 18:8228-8235.

Glushakov AV, Glushakova HY, Skok VI (1999) Modulation of nicotinic acetylcholine receptor activity in submucous neurons by intracellular messengers. J Auton Nerv Syst 75:16-22.

Halevi S, Yassin L, Eshel M, Sala F, Sala S, Criado M, Treinin M (2003) Conservation within the RIC-3 gene family. Effectors of mammalian nicotinic acetylcholine receptor expression. J Biol Chem 278:34411-34417.

Hanke JH, Gardner JP, Dow RL, Changelian PS, Brissette WH, Weringer EJ, Pollok BA, Connelly PA (1996) Discovery of a novel, potent, and Src family-selective tyrosine kinase inhibitor. Study of Lck- and FynTdependent $\mathrm{T}$ cell activation. J Biol Chem 271:695-701.

Haselbeck RC, Berg DK (1996) Tyrosine kinase inhibitors alter composition of nicotinic receptors on neurons. J Neurobiol 31:404-414.

Henderson LP, Gdovin MJ, Liu C, Gardner PD, Maue RA (1994) Nerve growth factor increases nicotinic $\mathrm{ACh}$ receptor gene expression and current density in wild-type and protein kinase A-deficient PC12 cells. J Neurosci 14:1153-1163.

Herzig S, Neumann J (2000) Effects of serine/threonine protein phosphatases on ion channels in excitable membranes. Physiol Rev 80:173-210.

Hopfield JF, Tank DW, Greengard P, Huganir RL (1988) Functional modulation of the nicotinic acetylcholine receptor by tyrosine phosphorlyation. Nature 336:677-680.

Jones S, Yakel JL (1997) Functional nicotinic ACh receptors on interneurones in the rat hippocampus. J Physiol (Lond) 504:603-610.

Kassner PD, Berg DK (1997) Differences in the fate of neuronal acetylcholine receptor protein expressed in neurons and stably transfected cells. J Neurobiol 33:968-982.

Kawai H, Berg DK (2001) Nicotinic acetylcholine receptors containing $\alpha 7$ 
subunits on rat cortical neurons do not undergo long-lasting inactivation even when up-regulated by chronic nicotine exposure. J Neurochem 78:1367-1378.

Kawai H, Zago W, Berg DK (2002) Nicotinic $\alpha 7$ receptor clusters on hippocampal GABAergic neurons: regulation by synaptic activity and neurotrophins. J Neurosci 22:7903-7912.

Kohr G, Seeburg PH (1996) Subtype-specific regulation of recombinant NMDA receptor-channels by protein tyrosine kinases of the src family. J Physiol (Lond) 492:445-452.

Krause RM, Buisson B, Bertrand S, Corringer PJ, Galzi JL, Changeux JP, Bertrand D (1998) Ivermectin: a positive allosteric effector of the $\alpha 7$ neuronal nicotinic acetylcholine receptor. Mol Pharmacol 53:283-294.

Liu L, Brown III JC, Webster WW, Morrisett RA, Monaghan DT (1995) Insulin potentiates $\mathrm{N}$-methyl-D-aspartate receptor activity in Xenopus oocytes and rat hippocampus. Neurosci Lett 192:5-8.

Liu QS, Berg KD (1999) Actin filaments and the opposing actions of CaM kinase II and calcineurin in regulating $\alpha 7$-containing nicotinic receptors on chick ciliary ganglion neurons. J Neurosci 19:10280-10288.

Liu Y, Ford B, Mann MA, Fischbach GD (2001) Neuregulins increase $\alpha 7$ nicotinic acetylcholine receptors and enhance excitatory synaptic transmission in GABAergic interneurons of the hippocampus. J Neurosci 21:5660-5669.

Malinow R, Malenka RC (2002) AMPA receptor trafficking and synaptic plasticity. Annu Rev Neurosci 25:103-126.

Mansvelder HD, McGehee DS (2002) Cellular and synaptic mechanisms of nicotine addiction. J Neurobiol 53:606-617.

Margiotta JF, Berg DK, Dionne VE (1987) Cyclic AMP regulates the proportion of functional acetylcholine receptors on chicken ciliary ganglion neurons. Proc Natl Acad Sci USA 84:8155-8159.

Marks MJ, Burch JB, Collins AC (1983) Effects of chronic nicotine infusion on tolerance development and nicotinic receptors. J Pharmacol Exp Ther 226:817-825.

McNiven MA, Cao H, Pitts KR, Yoon Y (2000) The dynamin family of mechanoenzymes: pinching in new places. Trends Biochem Sci 25:115120.

Mei L, Si J (1995) Tyrosine phosphorylation and synapse formation at the neuromuscular junction. Life Sci 57:1459-1466.

Meyer G, Wallace BG (1998) Recruitment of a nicotinic acetylcholine receptor mutant lacking cytoplasmic tyrosine residues in its $\beta$ subunit into agrin-induced aggregates. Mol Cell Neurosci 11:324-333.

Molinari EJ, Delbono O, Messi ML, Renganathan M, Arneric SP, Sullivan JP, Gopalakrishnan M (1998) Up-regulation of human $\alpha 7$ nicotinic receptors by chronic treatment with activator and antagonist ligands. Eur J Pharmacol 347:131-139.

Montecucco C, Schiavo G (1985) Structure and function of tetanus and botulinum neurotoxins. Q Rev Biophys 28:423-472.

Moss SJ, McDonald BJ, Rudhard Y, Schoepfer R (1996) Phosphorylation of the predicted major intracellular domains of the rat and chick neuronal nicotinic acetylcholone receptor $\alpha 7$ subunit by cAMP-dependent protein kinase. Neuropharmacology 35:1023-1028.

Neely A, Lingle CJ (1986) Trapping of an open-channel blocker at the frog neuromuscular acetylcholine channel. Biophys J 50:981-986.

Papke RL, Thinschmidt JS (1998) The correction of $\alpha 7$ nicotinic acetylcholine receptor concentration-response relationships in Xenopus oocytes. Neurosci Lett 256:163-166.

Papke RL, Bencherif M, Lippiello P (1996) An evaluation of neuronal nicotinic acetylcholine receptor activation by quaternary nitrogen compounds indicates that choline is selective for the $\alpha 7$ subtype. Neurosci Lett 213:201-204.

Peng X, Gerzanich V, Anand R, Wang F, Lindstrom J (1997) Chronic nicotine treatment up-regulates $\alpha 3$ and $\alpha 7$ acetylcholine receptor subtypes ex- pressed by the human neuroblastoma cell line SH-SY5Y. Mol Pharmacol 51:776-784.

Pereira EF, Reinhardt-Maelicke S, Schrattenholz A, Maelicke A, Albuquerque EX (1993) Identification and functional characterization of a new agonist site on nicotinic acetylcholine receptors of cultured hippocampal neurons. J Pharmacol Exp Ther 265:1474-1491.

Qian Y, Galli A, Ramamoorthy S, Risso S, DeFelice LJ, Blakely RD (1997) Protein kinase $\mathrm{C}$ activation regulates human serotonin transporters in HEK-293 cells via altered cell surface expression. J Neurosci 17:45-57.

Qu Z, Apel ED, Doherty CA, Hoffman PW, Huganir RL (1996) The synapse-associated protein Rapsyn regulates tyrosine phosphorylation of proteins colocalized at nicotinic acetylcholine receptor clusters. Mol Cell Neurosci 8:171-184.

Quick MW, Lester HA (1994) Methods for expression of excitability proteins in Xenopus oocytes. In: Methods in neuroscience (Conn PM, ed), pp 261-279. San Diego: Academic.

Rakhilin S, Drisdel RC, Sagher D, McGehee DS, Vallejo Y, Green WN (1999) $\alpha$-Bungarotoxin receptors contain $\alpha 7$ subunits in two different disulfidebonded conformations. J Cell Biol 146:203-218.

Ridley DL, Rogers A, Wonnacott S (2001) Differential effects of chronic drug treatment on $\alpha 3^{*}$ and $\alpha 7$ nicotinic receptor binding sites, in hippocampal neurones and SH-SY5Y cells. Br J Pharmacol 133:1286-1295.

Schwartz RD, Kellar KJ (1983) Nicotinic cholinergic receptor binding sites in the brain: regulation in vivo. Science 220:214-216.

Seguela P, Wadiche J, Dineley-Miller K, Dani JA, Patrick JW (1993) Molecular cloning, functional properties, and distribution of rat brain $\alpha 7$ : a nicotinic cation channel highly permeable to calcium. J Neurosci 13:596-604.

Sheng M (2001) Molecular organization of the postsynaptic specialization. Proc Natl Acad Sci USA 98:7058-7061.

Sheng M, Kim MJ (2002) Postsynaptic signaling and plasticity mechanisms. Science 298:776-780.

Skeberdis VA, Lan J-A, Zheng X, Zukin RS, Bennett MVL (2001) Insulin promotes rapid delivery of $N$-methyl-D-aspartate receptors to the cell surface by exocytosis. Proc Natl Acad Sci USA 98:3561-3566.

Sterling H, Lin DH, Gu RM, Dong K, Hebert SC, Wang WH (2002) Inhibition of protein-tyrosine phosphatase stimulates the dynamin-dependent endocytosis of ROMK1. J Biol Chem 277:4317-4323.

Sterling H, Lin DH, Wei Y, Wang WH (2003) Tetanus toxin abolishes exocytosis of ROMK1 induced by inhibition of protein tyrosine kinase. Am J Physiol Renal Physiol 284:F510-F517.

Sudhof TC (2004) The synaptic vesicle cycle. Annu Rev Neurosci 27:509-547.

Sweileh W, Wenberg K, Xu J, Forsayeth J, Hardy S, Loring RH (2000) Multistep expression and assembly of neuronal nicotinic receptors is both host-cell- and receptor-subtype-dependent. Mol Brain Res 75:293-302.

Wallace BG, Qu Z, Huganir RL (1991) Agrin induces phosphorylation of the nicotinic acetylcholine receptor. Neuron 6:869-878.

Wang K, Hackett JT, Cox ME, Van Hoek M, Lindstrom JM, Parsons SJ (2004) Regulation of the neuronal nicotinic acetylcholine receptor by SRC family tyrosine kinases. J Biol Chem 279:8779-8786.

Wang YT, Salter MW (1994) Regulation of NMDA receptors by tyrosine kinases and phosphatases. Nature 369:233-235.

White MM, Aylwin M (1990) Niflumic and flufenamic acids are potent reversible blockers of Ca-activated $\mathrm{Cl}$ channels in Xenopus oocytes. Mol Pharmacol 37:720-724.

Yang X, Kuo Y, Devay P, Yu C, Role L (1998) A cysteine-rich isoform of neuregulin controls the level of expression of neuronal nicotinic receptor channels during synaptogenesis. Neuron 20:255-270.

Zwart R, Oortgiesen M, Vijverberg HPM (1995) Differential modulation of $\alpha 3 \beta 2$ and $\alpha 3 \beta 4$ neuronal nicotinic receptors expressed in Xenopus oocytes by flufenamic acid and niflumic acid. J Neurosci 15:2168-2178. 